\title{
Micro-scale heterogeneity of spiders (Arachnida: Araneae) in the Soutpansberg, South Africa: a comparative survey and inventory in representative habitats
}

\author{
S.H. Foord ${ }^{*}$, M.M. Mafadza', A.S. Dippenaar-Schoeman² \& B.J. Van Rensburg ${ }^{3}$ \\ ${ }^{1}$ Department of Biological Sciences, University of Venda, Thohoyandou, 0950 South Africa \\ ${ }^{2}$ ARC-Plant Protection Research Institute, Biosystematics Division, Private Bag X134, Queenswood, 0121 South Africa \\ and Department of Zoology and Entomology, University of Pretoria, Pretoria, 0002 South Africa \\ ${ }^{3}$ Centre for Invasion Biology and Department of Zoology and Entomology, University of Pretoria, Pretoria, \\ 0002 South Africa \\ Received 5 October 2007. Accepted 11 June 2008
}

\begin{abstract}
Coarse-scale studies that focus on species distributions and richness neglect heterogeneity that may be present at finer scales. Studies of arthropod assemblage structure at fine $(1 \times$ $1 \mathrm{~km})$ scales are rare, but important, because these are the spatial levels at which real world applications are viable. Here we investigate fine-scale variation in spider assemblages, comparing five representative vegetation types in the western Soutpansberg, Limpopo Province, South Africa. We assess these vegetation types in terms of their family and species composition, as well as levels of endemicity, relating these differences with vegetation structure. We inventoried 297 species (49 families) in an area less than 450 ha, as part of South African National Survey of Arachnida. Analysis of the results suggests that endemic taxa are associated with Tall Forest and, to a lesser extent, Woodland. The Woodland had the highest species diversity, and much of the variation observed in spider assemblage structure is explained by these two vegetation types. Based on vegetation structure variables that explained significant variation in spider assemblages, human influence through bush encroachment will result in a change of spider assemblages to that of Short Forest and Mosaic Woodland vegetation types, with implications for biodiversity maintenance and heterogeneity.
\end{abstract}

Key words: endemicity, South Africa, spider, SANSA, conservation, Soutpansberg.

\section{INTRODUCTION}

If a country's conservation goal is to retain as much of the region's biodiversity as possible, then the delineation of spatial heterogeneity in communities or assemblages at the local scale is an important step towards achieving this. That is, information on the extent to which local biotas vary between and within habitat types is necessary for a better understanding of the underlying processes explaining local community patterns (Ricklefs 1987; Cornell 1993). Priority conservation areas identified at broad global or regional scales are often heterogeneous and cannot be translated into effective local conservation strategies without reference to local landscape and species distribution patterns. This is because local heterogeneity can be present across scales and may significantly complicate the development of effective regional conservation strategies (Flather et al. 1997; Rodrigues et al. 1999). The identification of fine-scale spatial

*Author for correspondence. E-mail: sfoord@univen.ac.za heterogeneity in local biotas is therefore important because: (i) such information will enhance areaselection techniques (which are currently mostly conducted at coarse regional scales) to select units defined at the scale of land management units (Wiens 1989; Flather et al. 1997; Rodrigues et al. 1999), and (ii) long-term conservation of the biota that constitutes these heterogeneous communities will be achieved (Rodrigues et al. 1999).

The Soutpansberg is a major centre of plant endemism and biodiversity, and has the highest plant generic and family level diversity among the 18 recognized Centres of Plant Endemism (CPEs) for southern Africa (Van Wyk \& Smith 2001). Recent botanical studies conducted in the Soutpansberg estimate a total of 3000 plant species including 1066 genera (the world-renowned Cape Floral Kingdom has 1000 genera) (Hahn 2002). The region also contains: (i) 33\% of South Africa's reptiles, 116 species in total, equalling that of the entire Kruger National Park (Berger et al. 2003); 
(ii) $60 \%$ of South Africa's mammal species, which represents more mammal species per unit area than seven of the eight most diverse biodiversity hotspots of the world (Berger et al. 2003); and (iii) $75 \%$ of South Africa's avifauna (Berger et al. 2003). Although the area was not rated as an urgent priority for conservation by Reyers (2003), the very high levels of biological diversity of the Soutpansberg gives it a high long-term priority for conservation (Van Wyk \& Smith 2001). It is also the site of a proposed Biosphere Reserve (UNESCO 2005) and a process has been initiated for the proposed Soutpansberg to Limpopo Biosphere Reserve (Hahn 2002). This process includes the identification of conservation hotspots that would form the basis for the selection of core conservation areas.

Spiders are a ubiquitous component of invertebrate assemblages and important generalist predators in ecosystems (Wise 2005) with the potential to complement existing large-scale area selection activities based on vertebrates (Jocqué \& Dippenaar-Schoeman 2006). They are known to be sensitive towards fine-scale changes in environmental factors, are relatively easy to identify based on external genitalia and have the potential to act as indicators of habitat quality and conservation value (Jocqué 1981). Spiders are a 'hyperdiverse' taxon, and because of a general awareness of spiders within the public realm, have the potential to act as a focal taxon for conservation assessments (New 1999). Recent developments in South Africa have added weight to this suggestion with the inclusion of spiders in conservation assessments and red listing of species (Dippenaar-Schoeman \& Haddad 2006). The South African National Survey of Arachnida (SANSA) and its recent collaboration with the South African National Biodiversity Institute will provide the critical information needed for this process (Dippenaar-Schoeman \& Craemer 2000).

Contemporary research has shown that, at least for certain invertebrate groups such as spiders, the eastern parts of South Africa have comparable levels of endemism, at both the generic and specific levels, to that of the Cape Floral Kingdom and Succulent Karoo (Huber 2003). Although levels of endemicity seem to be high, very little is known about the levels of invertebrate diversity in the Soutpansberg, and the region in general, has been poorly surveyed with only 13 survey sites (and an average of 13 records per site). Determining conservation priorities for spiders, namely core areas and buffer zones as set out in biosphere reserve planning, is therefore not viable because of a paucity of data.

Here we attempt to use information on spiders to estimate the relative conservation importance of the dominant vegetation types in the western Soutpansberg. This area is climatically and topographically the most varied part of the Soutpansberg, and recent ad hoc collections recorded 47 spider families $(74 \%$ of the known families from South Africa) in an area less than 450 ha. We initiated a quantitative small-scale survey in this same area, which afforded the following opportunities: (i) contributing to SANSA's database by inventorying spiders and measuring species richness, abundance and endemicity in major vegetation types of the Soutpansberg, (ii) determining whether spider assemblage structure differed between the major vegetation types at a fine scale and how restricted taxa are to these habitats, and (iii) establishing which, and to what extent, vegetation structure variables are related to these differences.

\section{METHODS}

\section{Study area}

Fieldwork was conducted in the western parts of the Soutpansberg mountain range situated near the northern border of South Africa with Zimbabwe. The mountain forms a geographic unit with the Makgabeng Plateau, Blouberg Mountain to the west and the Waterberg to the south.

Transects were set out on the farm Lajuma $\left(23^{\circ} 1.49^{\prime} \mathrm{S}, 29^{\circ} 25.74^{\prime} \mathrm{E}\right)$ that has a surface area of $430 \mathrm{ha}$. The highest point of the mountain range, Letjume (1747 $\mathrm{m}$ a.s.l), is on Lajuma and is c. $800 \mathrm{~m}$ above the surrounding plains (Gaigher 2006). Average annual rainfall at Lajuma is $730 \mathrm{~mm}$, varying considerably from year to year (Gaigher 2006). Commercial farming in the western Soutpansberg has resulted in vegetation that mainly consists of thickets and scrublands, vegetation with patches of grass and fragmentary groundwater forests below cliffs. Higher altitudes are characterized by areas with an interesting mosaic vegetation type consisting of short grassland and 'islands' of closed woody cover.

\section{Sampling and analytical procedures}

Five representative vegetation types, based on broad-scale structural classification (Edwards 1983) of the western Soutpansberg were identified, namely Tall Forest (TF) or Evergreen Northern 
Mistbelt Forest (Mucina et al. 2005), 10-20 m high and characterized by plant species such as Rhus chirindensis, Gymnosporia havianus, and Eugenia natalitia with a weakly developed understorey; Short Forest (SF) or Semi-deciduous Northern Mistbelt Forest (Mucina et al. 2005), 5-10 m high, that is dominated by Canthium mundianum, Gymnosporia buxifolia, Catha edulis, and variably developed understorey; Woodland (W) distinguished by Mundulea sericea, Dovyalis zeyheri, and Dichrostachys cenerea with a well-developed understorey of grass; Mosaic Woodlands (MW) dominated by Mundulea sericea, Gymnosporia buxifolia and Canthium mundianum with a very weakly developed understorey, and finally, Mosaic Grasslands (MG) dominated by Pteridium aquilinium in sandy soils. The altitudes of sites varied between $1270-1420 \mathrm{~m}$ a.s.l. All vegetation types were within $2 \mathrm{~km}$ of each other on the property and within each, five replicated transects $(3 \mathrm{~m} \times 50 \mathrm{~m})$ were set out.

\section{Spiders}

Within each transect $(3 \times 50 \mathrm{~m})$, five sampling techniques were used to collect spiders from different strata, subject to the availability of substrate. First, beating was done by randomly selecting four trees, all different species, within each transect. These were beaten 20 times each by firmly striking the tree branches with a $(>1.5 \mathrm{~kg})$ mallet. A white beating sheet was held below branches during beating, from which all spiders were collected and preserved in $70 \%$ alcohol. All trees beaten were identified to species level. Second, a sweep net, $0.6 \mathrm{~m}$ in diameter and with a $1.2 \mathrm{~m}$ long handle was swept through the grass and herb layer. Each sweep covered an arc of approximately $1.5 \mathrm{~m}$ through the vegetation on every alternate step (Southwood \& Henderson 2000). Two samples, comprising 20 sweeps each, were done at each site. Samples were emptied into a plastic container, preserved using 70\% alcohol and sorted at a later stage, separating insects and spiders. Third, active searching, comprising three $1 \times 1 \mathrm{~m}$ quadrats, each searched for 15 minutes, was done at each site. The ground, shrubs, rocks, logs, bark and stones were thoroughly searched for spiders. Specimens were collected using either the handto-jar technique, or a mouth suction sampler. Fourth, a transect of five unbaited pitfall traps, $10 \mathrm{~m}$ apart and flush with the surface of the ground, were inserted at each transect. Traps had a diameter of $9.5 \mathrm{~cm}$ and contained a $50 \mathrm{ml}$ solution of three parts $70 \%$ ethyl alcohol and one part glycerol. The samples were emptied on a weekly basis and remained active for 14 days. Finally, leaf litter, in three $(1 \times 1 \mathrm{~m})$ randomly selected quadrates within each transect, was sifted through a $5 \mathrm{~mm}$ mesh sieve, onto a white sheet. Specimens were collected with a mouth suction sampler and preserved in $70 \%$ alcohol.

The Soutpansberg region has two clearly differentiated seasons: the cool dry season from May to August and the warm, wet season from October to March (Gaigher 2006). Each transect was sampled three times during 2004 and 2005 in autumn (May 2004), early summer (November 2004), and late summer (March 2005) to account for seasonal variability and to minimize temporal edge effects that result from collecting juveniles for a given species.

For analysis, the numbers of individuals of each species collected via the different sampling techniques over the course of the study period were summed for each sampling site. All samples, except pitfall trapping, were collected between 09:00 and 15:00 in cloud cover less than $50 \%$, so as to standardize weather conditions under which sampling was conducted and reduce confounding effects. Spiders (adults and juveniles) were sorted to family level by the first two authors. Species level identifications were done by the third author, except for the family Corinnidae, which was done by C.R. Haddad (Department of Entomology and Zoology, University of the Free State, South Africa). Voucher specimens are housed in the National Collection of Arachnida at the Agricultural Research Council, Plant Protection Research Institute in Pretoria.

\section{Vegetation structure}

To determine the extent to which small-scale vegetation structure might affect spider assemblage composition and structure each transect was divided into 16 blocks of $9 \mathrm{~m}^{2}$, and one block of $6 \mathrm{~m}^{2}$ (the block in the middle), and measurements of the percentage of grass, herb, shrub, tree and rock cover were made in each block. Plant species identity and foliage height were also recorded. All woody plants over $1.5 \mathrm{~m}$ tall were recorded as trees, and those smaller than $1.5 \mathrm{~m}$ as shrubs. Lowest foliage height of trees was determined. Tree and shrub diameters were measured $1.3 \mathrm{~m}$ and $20 \mathrm{~cm}$ above ground, respectively. All branches separated from their main stem at the diameter measuring point, were referred to as stems. These measurements were all taken at the start of the 
study. The vegetation structure variables for a transect were calculated as the average for all the blocks within that transect.

\section{Data analysis}

In this study, sampling points were assumed to be independent from each other. However, the presence of spatial autocorrelation within ecological data may invalidate the assumption of independence (Legendre 1993). Spatial autocorrelation is the lack of independence between pairs of observations at given distances in space and is commonly found in ecological data, and can inflate Type 1 errors in statistical analysis (Diniz-Filho et al. 2003). Although these tests are also used to assess the spatial structuring of communities, the objective of the analysis for this study was to assess the extent of independence among the five transects within each vegetation type. This was done using a BrayCurtis similarity matrix, calculated by square-root transformation of the data before analysis (Clarke \& Warwick 2001), in conjunction with a distance matrix (in metres) as input data for a Mantel test (Mantel V.2; Liedloff 1999; Koenig 1999).

Total species richness and abundance were determined for each vegetation type. The number of individuals and species sampled was summed for each transect over all three sampling periods from which the mean species richness and abundance were calculated across the five transects for each vegetation type. The mean species richness and abundance were compared between vegetation types using analysis of variance and Tukey HSD tests.

To examine how representative the spider assemblages sampled in each vegetation type were relative to the expected true diversity of these assemblages, the assemblages were assessed based on sample-based rarefaction species richness estimators using EstimateS v7.5 (Colwell 1994-2004; Gotelli \& Colwell 2001). Comparisons have shown that the ICE (Incidence-based Coverage Estimator) richness estimator performs the best (Colwell \& Coddington 1994; Scharff et al. 2003). The ratio of observed richness to ICE for each vegetation type, i.e. inventory completeness, provided an estimate of sampling completeness. The Coleman method of individual-based rarefaction (Coleman 1981) was used to compare species richness of the vegetation types based on the lowest number of individuals caught in all the vegetation types. Species specific to each vegetation type were identified. The number and percentage of species shared between vegetation types were also estimated to assess the similarity in species composition of vegetation types.

To investigate if spider assemblages differed between the vegetation types, analysis of similarity (ANOSIM), using PRIMER v6.1.6 (Clarke \& Warwick 2001), was used to establish the significance of differences. This is a non-parametric permutation procedure applied to rank similarity matrices underlying sample ordinations (Clarke \& Warwick 1994), in which a significant global $R$-statistic of close to one indicates distinct differences between the assemblages/vegetation types compared. All species abundances were squareroot transformed prior to analysis to down-weight effects of more common species (Clarke \& Warwick 1994). Non-metric multidimensional scaling (MDS) was used to display the unconstrained relationships between transects in an ordination analysis.

Relationship of spider assemblages and vegetation structure within each transect was examined with redundancy analysis RDA, a constrained method of ordination (CANOCO V4.5: Ter Braak \& Šmilauer 2002). A forward selection procedure was used to identify vegetation structure variables that significantly explained spider assemblage structure. Species sample relationships were also displayed as biplots to determine which species contributed to differences between assemblages. Only species with more than $70 \%$ of their variability explained by the biplot were included. Species are depicted as arrows pointing in the direction of the steepest increase in abundance (Botes et al. 2006; Lepš \& Šmilauer 2003).

\section{RESULTS}

A total of 9985 individuals was collected over the three sampling periods. Seventy-three per cent of these specimens were juveniles. Of all the adults collected, the highest proportion $(34 \%)$ was collected during November. The spiders caught represent 297 species in 156 genera, and 43 families (Appendix 1). Forty-five per cent (124) of these were only identified to morphospecies level. The study adds two new families (Oonopidae and Orsolobidae) to the list recorded for Lajuma, and brings the total to 49 (Appendix 1; Foord et al. 2002). In addition, 183 species were new records for the region, and two new genera (one corinnid and one araneid genus), and seven possibly new species for science were discovered. The capture of specimens of the zodariid genus, Australutica 
africana Jocque 2008, represents the first record of this genus outside Australia (Jocqué 2008). Specimens of a new corinnid genus, subfamily Corinninae, have only been collected from the Soutpansberg (C.R. Haddad, pers. comm. 2008). The five most abundant families, in rank order, were Lycosidae (1397 individuals), Theridiidae (1099), Thomisidae (839), Linyphiidae (733), and Salticidae (715), whereas the most species diverse family was Thomisidae with 39 species, followed by Theridiidae with 36 species. The genera Theridion and Oxyopes were the most species rich, with 13 and 11 species, respectively.

The inventory completeness (i.e. species observed as a percentage of species estimated through ICE) in four of the five vegetation types examined, Mosaic Woodland, Short Forest, Tall Forest, and Woodland, were 70\% and higher (Fig. 1). Because spiders are a hyperdiverse group, most surveys suffer from some degree of under-sampling, although the results from our study compares well with other inventories (Toti et al. 2000; Scharff et al. 2003). However, due to the extremely low levels of inventory completeness in mosaic grasslands, $45 \%$, all data from this vegetation type were excluded from subsequent analysis.

Except for the Tall Forest $(R=-0.67, P=0.036$, $n=10$ ), spatial autocorrelation had a non-significant effect on the sampling designs of the vegetation types examined (Short Forest: $R=0.15, P=$ $0.68, n=10$; Woodland: $R=-0.62, P=0.06, n=10$; Mosaic Woodland: $R=0.27, P=0.44, n=10$ ). The replicates, in general, therefore do not suffer from pseudoreplication (see Hurlbert 1984 for explanation) and the extent to which the spider assemblages varied across the vegetation types examined can therefore be treated as robust.

Tall Forest had fewer species (rarified estimate) than Mixed Woodland and Short Forest, which had similar numbers of species, and Woodland had the highest species richness (Table 1). Spider abundance was highest in the Woodland and Tall Forest, less in the Short Forest, and least in Mosaic Woodland.

Four families, Theraphosidae (MW), Migidae (TF), Phyxelididae (SF), and Sicariidae (TF), were restricted to single vegetation types. Eleven per cent of the species caught in the Mosaic Woodland was specific to this vegetation type, $10 \%$ to the Short Forest, $7.5 \%$ to the Tall Forest, and $16 \%$ in the Woodlands (Appendix 1). The unconstrained relationships between sites based on spider community composition are summarized by the ordination in Fig. 2. Analysis of similarity indicated significant differences in spider assemblage structure among all possible pairs of vegetation type comparisons (Table 2). The six Soutpansberg spider endemics collected in this study, namely Entypesa schoutedeni Benoit, 1965 (Nemesiidae), Quamtana entabeni Huber, 2003 and Q. lajuma Huber, 2003 (Pholcidae), Poecilomigas sp.1 (Migidae), and Hortipes contubernalis Bosselaers \& Jocqué, 2000 and Hortipes sp.4 (Corinnidae) were either restricted or positively correlated with Tall Forest, and to a lesser extent in Woodlands (Fig. 3).

Only $27.4 \%$ of the 297 species recorded were shared between the four habitats. In terms of assemblage membership, Short Forest is transitional between the other three habitats, sharing on average most of its species. This is confirmed by the ordination of assemblage structure (Fig. 2). Global $R$ values are very high (>0.639) and highly significant for all the spider assemblage comparisons, indicating distinct differences between the vegetation types except for Tall Forest $v$ S Short Forest, and Short Forest $v s$ Mixed Woodland comparisons, where the $R$ values were $<0.502$ (Table 2; Fig. 2). Woodland and Tall Forest were separated along the first RDA axis that explained $29.7 \%$ of the relationship between assemblages and environmental variables $(F=6.35, P=0.002)$ and the first and second axes together explained $41.5 \%$. Four of the vegetation structure variables contributed significantly to the variance explained in spider assemblages, namely lowest foliage of trees, grass cover, herb cover, and tree density (Table 3, Fig. 4a). The first axis represents an environmental gradient of increasing foliage height of trees, decreasing herb and grass cover. The second axis represents increasing trees density. Therefore, vegetation structure variables measured during this study, clearly explain a large percentage of the differences between spider assemblages in the four vegetation types. The abundances of several species were positively associated with Tall Forest and Woodland but none with Mosaic Woodland and Short Forest (Fig. 4b).

\section{DISCUSSION}

Levels of spider diversity of the western Soutpansberg are relatively high compared to those of other South African and African surveys (Table 4). The current study has therefore made a significant contribution towards the existing SANSA database. Only one other study in South Africa (see Haddad et al. 2006) has recorded more species (431 


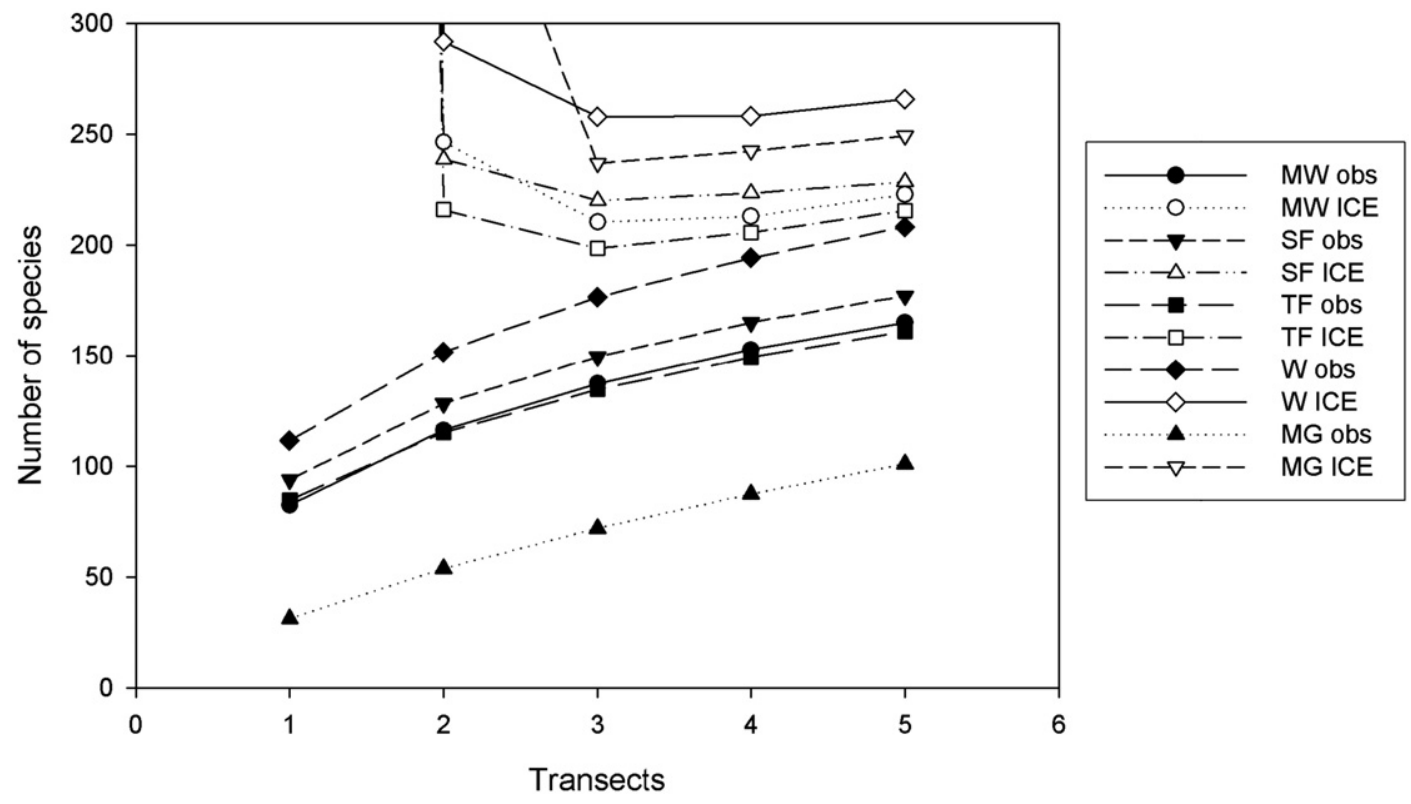

Fig. 1. Species rarefaction curves of vegetation types. $M G=$ Mosaic Grassland, MW = Mosaic Woodland, $S F=S h o r t$ Forest, TF = Tall Forest, $\mathrm{W}=$ Woodland, obs = observed number of species, ICE = Incidence Coverage Estimator.

vs 367) and genera (222 vs 191) (Table 4). Haddad et al. (2006) collected spiders on an ad hoc basis for six years in eight broad habitat types in the Ndumo Game Reserve, Maputaland (10117 ha), more than an order of magnitude larger than Lajuma (Table 4). At the family level, Haddad et al. (2006) recorded 46 taxa, three less than that recorded at Lajuma. One other study recorded more families, 52, in the De Hoop Nature Reserve (Haddad \& Dippenaar-Schoeman, in press) but with a spatial extent two orders of magnitude larger than this study (Table 4).

Considering the different vegetation patches that were sampled in this study, Tall Forest had the lowest species richness (rarified) and Woodland the highest. By contrast, Tall Forest and Woodland had the highest abundance of spiders, significantly higher than that of Mosaic Woodland. Variation in sampling intensity, a factor not considered here, most likely contributed towards these differences in richness and abundance. For example, the high species richness associated with Woodland is positively affected by the well-developed grass layer's effect on sweep net sampling that was much less effective in vegetation types with a poorly developed understorey, such as Tall Forest and Mosaic Woodland. However, the sampling intensities for all the other sampling methods were broadly comparable.

Almost all the endemic taxa in this study were associated with Tall Forest. Biogeographically, Tall Forest is classified as Northern Mistbelt Forests, (Mucina et al. 2005) and the sites sampled represent one of a group of distinct isolated patches

Table 1. Total species density and abundances for spiders collected in the Tall Forest, Short Forest, Mosaic Woodland and Woodland vegetation types in the western Soutpansberg

\begin{tabular}{|c|c|c|c|c|c|c|}
\hline Habitat & Density mean \pm S.E. & Abundance mean \pm S.E. & $n$ & s & S & $\mathrm{N}$ \\
\hline Mosaic Woodland & $82.4 \pm 3.47^{a}$ & $356.0 \pm 25.23^{b}$ & 5 & 154 & 165 & 1780 \\
\hline Short Forest & $93.8 \pm 4.71^{\mathrm{a}}$ & $487.2 \pm 28.68^{a}$ & 5 & 150 & 177 & 2436 \\
\hline Tall Forest & $84.8 \pm 2.22^{a}$ & $551.6 \pm 45.79^{a}$ & 5 & 127 & 161 & 2758 \\
\hline Woodland & $111.4 \pm 2.54_{b}$ & $540.6 \pm 6.21^{a}$ & 5 & 175 & 208 & 2703 \\
\hline
\end{tabular}

$n=$ number of sampling sites, $\mathrm{s}=$ total species richness (rarified), $\mathrm{S}=$ total species density (observed number of species),

$\mathrm{N}=$ total abundance. Means with no letters in common denote significant differences between habitat types of $P<0.05$. 


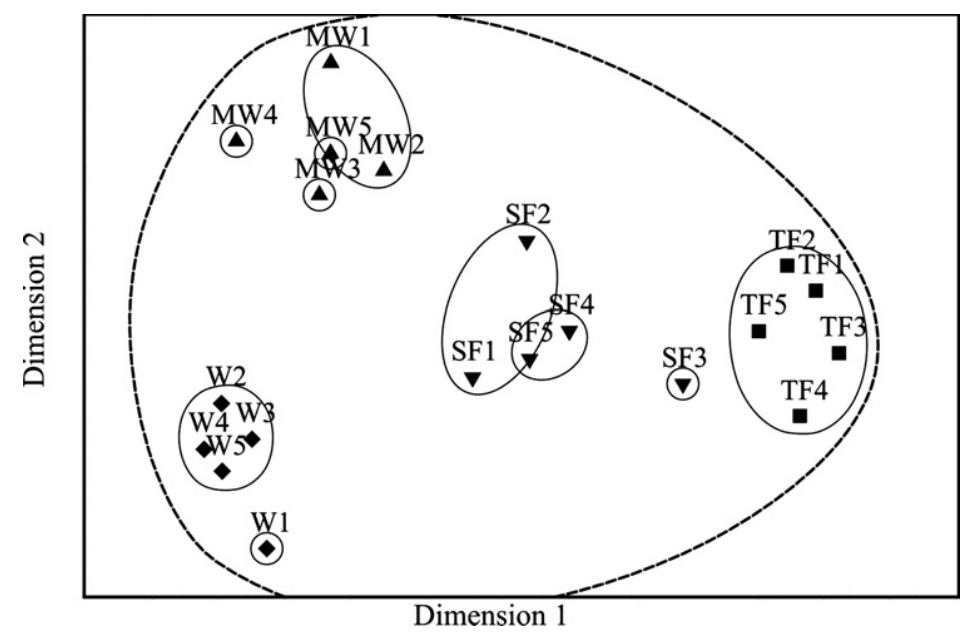

Fig. 2. Unconstrained ordination plot of the five replicated sites in each of the four vegetation types based on multidimensional scaling of the spider assemblages.

scattered throughout the Soutpansberg, varying in both size and isolation. Two of the five families recorded outside Lajuma, in the Soutpansberg, namely Archaeidae and Cyatholipidae, are restricted to the Northern Mistbelt Forests. With the exception of one species (Afrarchaea bergae Lotz, 1996), all the Soutpansberg records for these two families are endemic species (Lotz 2003; Griswold, 1987).

In contrast to studies in other regions, where high levels of plant endemism are mirrored by those of invertebrates (Botes et al. 2006; Haddad et al. 2006), no such relationship exists for Tall Forest. Only one plant taxon, Streptocarpus parviflorus subsp. soutpansbergensis, is endemic to Mistbelt Forests of the Soutpansberg (Hahn 2006). Most of the plant species endemic to the Soutpansberg are found in mountain sourveld, grasslands and xeric habitats, $47 \%$ are succulents (Hahn 2006). An important process that affects all the vegetation types with high endemism in this study area is mist precipitation. This is especially true in times of drought, and many of the plant endemics $(33.3 \%)$ are restricted to the mist belt. Little is known about mist interaction with the environment that is influenced by moisture-laden air from the Indian Ocean, orography, and aerodynamics (Hahn 2006). Recent arachnid surveys in the sourveld on the northern slopes of the mountain have also resulted in the description of two endemic arachnid taxa: a spider, Tyrotama soutpansbergensis (Foord \& DippenaarSchoeman 2005) and a scorpion, Hadogenes soutpansbergensis (Prendini 2006). The new corinnid genus and the zodariid genus, Australutica, were predominantly found in Mosaic Grassland and Woodlands, respectively (Appendix 1).

The differences in vegetation structure between the vegetation types examined resulted in the formation of different spider communities in the four vegetation types. The turnover of species

Table 2. Estimated number (from Estimate $S$ ) of spider species shared between habitats. TF $=$ Tall Forest, SF $=$ Short Forest, MW = Mosaic Woodland, W = Woodland.

\begin{tabular}{lcccc}
\hline Habitat & No. of species & No. shared species & \% Species shared & $R(P)$ \\
\hline TF and SF & 216 & 122 & 56.4 & $0.494(<0.002)$ \\
TF and MW & 228 & 98 & 42.9 & $0.795(<0.002)$ \\
TF and W & 252 & 117 & 46.4 & $0.977(<0.002)$ \\
SF and MW & 230 & 112 & 48.7 & $0.456(<0.002)$ \\
SF and W & 252 & 133 & 52.3 & $0.639(<0.002)$ \\
MW and W & 246 & 127 & 51.6 & $0.502(<0.002)$ \\
TF, SF, MW, and W & 295 & 81 & 27.4 & $0.967(<0.002)$ \\
\hline
\end{tabular}

Pair-wise ANOSIM Global $R$-test statistics and their associated significance. 


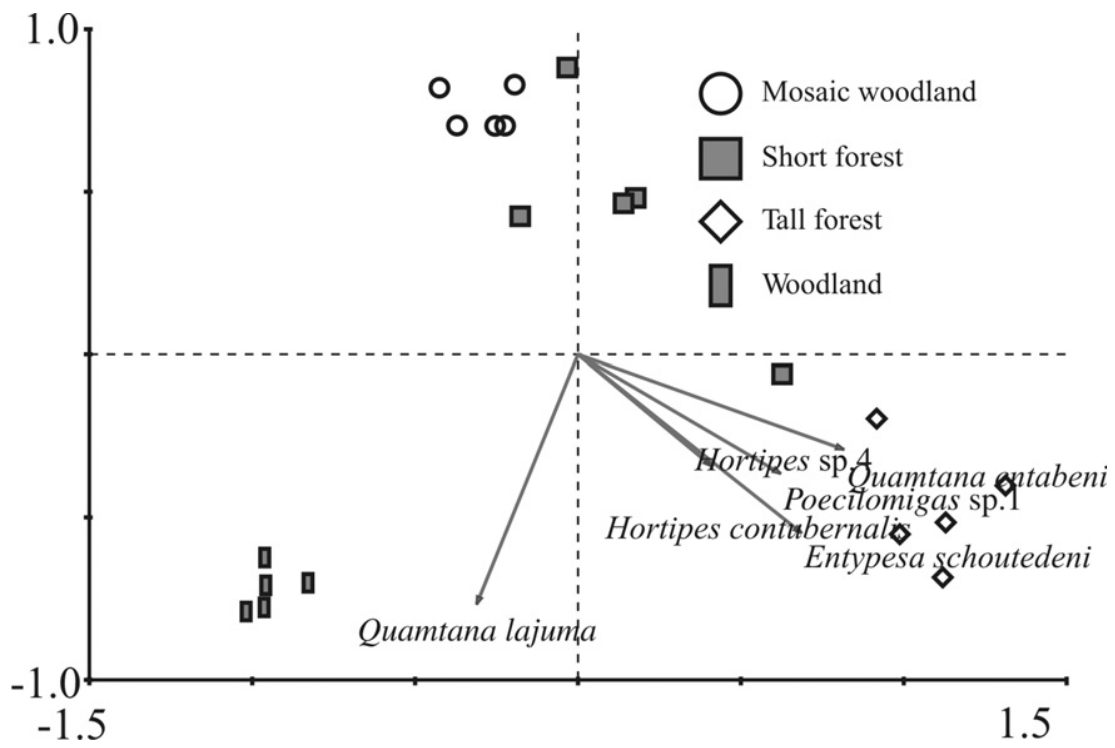

Fig. 3. Biplot of Soutpansberg spider endemics and the vegetation types that they are associated with.

between Tall Forest and Woodlands were the greatest (Fig. 2). In addition, all the species that had $70 \%$ of their variation explained by the RDA-ordination, were positively associated with these two habitats (Fig. 5b). Similar to other studies, for example Rypstra (1986) and Jiménez-Valverde \& Lobo (2007), our results suggest that vegetation structure, when compared among the habitats examined, is likely to contribute towards the differences between their associated spider assemblages. The large amount of variation explained by local variables, i.e. vegetation structure, is consistent with the suggestion that local processes plays a large role in determining spider diversity, as competition is more likely to occur between predators, and vegetation structure variables should therefore explain local diversity (Borges \& Brown

Table 3. Significant species-environmental correlation coefficients ( $R$-values, Ter Braak \& Šmilauer 2002) from redundancy analysis. The significance of the $R$-values was determined using Monte Carlo permutation tests ( $P=$ significance and $F=$ test statistic). Eigenvalues indicate the additional variance explained by each variable. TreLowFo = lowest foliage of trees, GrasCove = grass cover, TreDen = tree density, HerbCove = herb cover.

\begin{tabular}{lccc}
\hline Variable & Eigenvalues & $P$ & $F$ \\
\hline TreLowFo & 0.25 & 0.002 & 6.12 \\
GrasCove & 0.12 & 0.002 & 3.02 \\
TreDen & 0.09 & 0.002 & 2.62 \\
HerbCove & 0.05 & 0.032 & 1.56 \\
\hline
\end{tabular}

2004). This also confirms that spiders have predictable assemblages based on habitat structure (Uetz 1991, Borges \& Brown 2004).

Although broad generalizations regarding the spider diversity related to the vegetation types examined cannot be made as a result of low replication in the sampling design, a few potential trends with wider significance for spider conservation can be highlighted based on those patches that were sampled, and should be investigated further to examine the generality of these trends. First, the restricted distribution of taxa at the local scale, often overlooked at the broader regional scale (Flather et al. 1997), is confirmed by the observation that only $27.4 \%$ of the species were found in all the habitats, at a scale less than $2 \mathrm{~km}$ in extent. Second, significant differences in the spider assemblage structure largely explained by differences in vegetation structure, were found among the four vegetation types examined, suggesting local scale heterogeneity (but further investigations are needed to assess the robustness of this). Third, Tall Forests, although comparatively species poor, provide habitat for endemic taxa and we emphasize the role of this habitat to provide stable conditions for the evolution and survival of endemic spider species in spite of their limited geographic range (Borges \& Brown 2004). Fourth, Woodland had the highest species diversity.

The maintenance of this woodland and forest matrix is therefore vital for the maintenance of biodiversity in this region. The Soutpansberg 


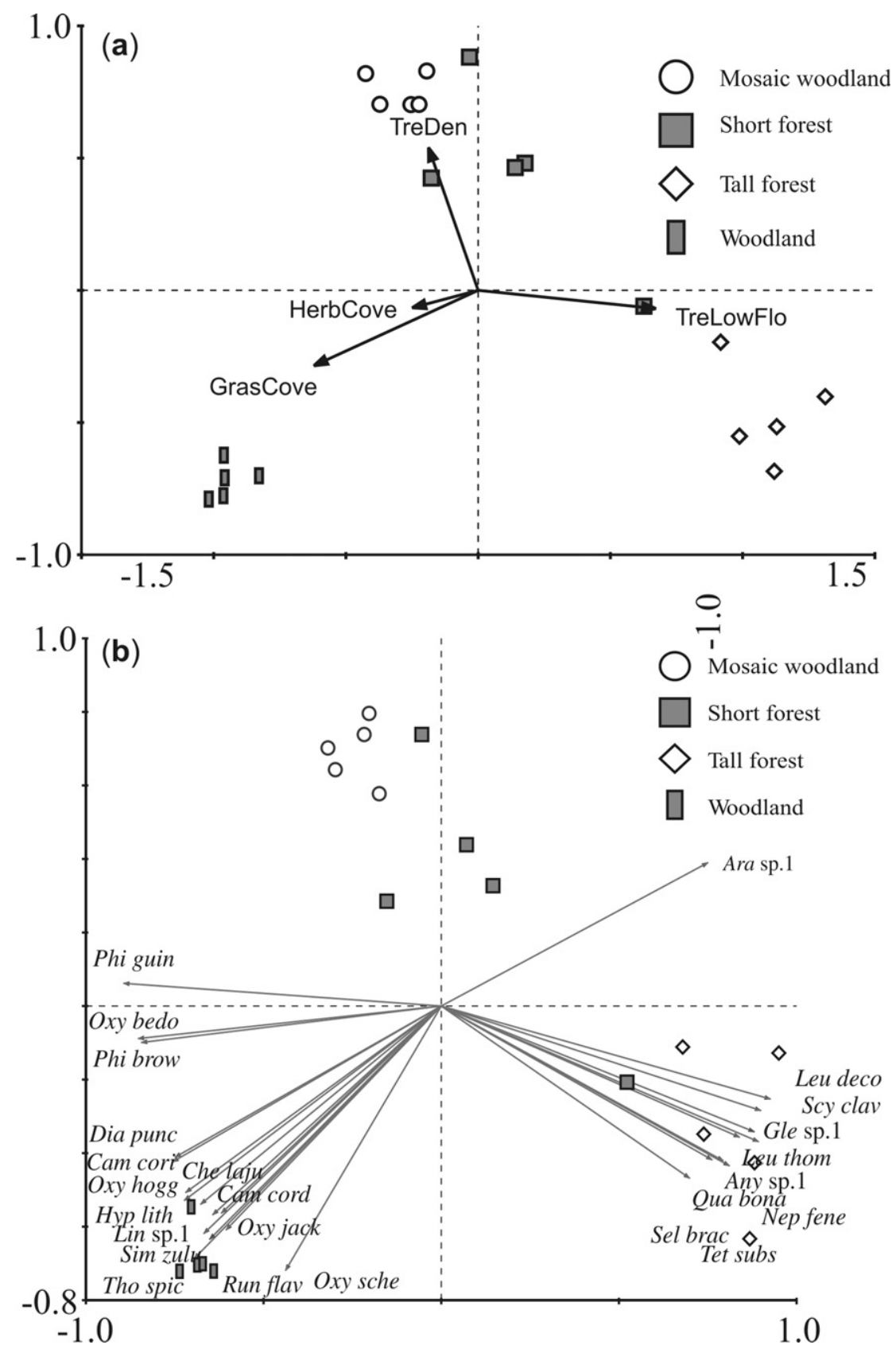

Fig. 4. RDA ordination (biplot, sample scaling) of (a) the spider assemblages occurring in the different vegetation types in relation to the environmental variables that explain significant amounts of variation. TreLowFo $=$ Tree lowest foliage, TreDen $=$ Tree density, HerbCove $=$ Herb cover, GrasCove $=$ Grass cover, and (b) the spider assemblages and species with more than $70 \%$ of their variability explained by the ordination subspace. Any sp. $1=$ Anyphops sp.1, Ara sp. 1 = Araneus sp.1, Cam cori = Cambalida cordiacea, Che laju = Cheiramiona lajuma, Dia punc = Diaea puncta, Gle sp.1 = Glenognatha sp.1, Hyp lith = Hypsosinga lithyphantoides, Leu deco = Leucauge decorata, Leu thom = Leucauge thomeensis, Nep fene = Nephila fenestrata, Oxy bedo = Oxyopes bedoti, Oxy jack = Oxyopes jacksoni, Oxy sche = Oxyopes schenkeli, Phi brow = Philodromus guineensis, Phi brow = Philodromus browningi, Qua bona = Quamtana bonamanzi, Run flav = Runcinia flavida, Sel brac = Selenops brachycephalus, Tet subs = Tetragnatha subsquamata, Tho spic $=$ Thomisus spiculosus. 
Table 4. Spider diversity recorded from protected areas in South Africa as ranked by currently known total family diversity.

\begin{tabular}{lcclr}
\hline Conservancy & Fam. & Spp. & Reference & Area (ha) \\
\hline De Hoop Nature Reserve & 52 & 252 & Haddad \& Dippenaar-Schoeman (in press) & 32729 \\
Lajuma Mountain Retreat & 49 & 367 & Present study \& Foord et al. (2002) & 450 \\
Ndumo Game Reserve & 46 & 431 & Haddad et al. (2006) & 10117 \\
Swartberg Nature Reserve & 45 & 186 & Dippenaar-Schoeman et al. (2005) & 129000 \\
Kruger National Park & 40 & 152 & Dippenaar-Schoeman \& Leroy (2003) & 2000000 \\
Polokwane Game reserve & 39 & 275 & Dippenaar et al. (2008) & 3200 \\
Makalali Game Reserve & 38 & 268 & Whitmore et al. (2001) & 22000 \\
Karoo National Park & 38 & 116 & Dippenaar-Schoeman et al. (1999) & 75000 \\
Mountain Zebra National Park & 34 & 76 & Dippenaar-Schoeman (2006) & 6536 \\
Roodeplaat Dam Nature Reserve & 27 & 110 & Dippenaar-Schoeman et al. (1989) & 795 \\
\hline
\end{tabular}

region has been experiencing a dramatic increase in bush encroachment over the last 150 years because of human influence, namely elimination of keystone herbivores, introduction of goats, and suppression of fires as a result of afforestation (Hahn 2006). Grasslands, specifically, have been under increasing pressure in the Soutpansberg and a very few remnant patches remain (Hahn 2006). Increased bush encroachment results in higher tree densities, and based on findings from this study, spider assemblages are likely to change into those represented by Mosaic Woodland and Short Forest, should such encroachment continue. These two vegetation types, generally, had lower species diversity and no endemic taxa. In addition, much of the variation of the spider assemblages in this study was explained by the two vegetation types most threatened in the Soutpansberg region, namely Woodlands and Tall Forests. Further bush encroachment would most certainly result in the loss of heterogeneity at this small scale and homogenization of spider assemblages as well as the loss of endemic taxa. Woodlands and tall mist forest are the vegetation types that should form the focus of core areas in the proposed biosphere with associated management initiatives to prevent bush encroachment in these areas.

\section{ACKNOWLEDGEMENTS}

This work was made possible by a NRF grant (GUN 2054390) to the first author (S.H.F.) and financial support from the University of Venda. B.J.V.R. acknowledges support from the DST-NRF Centre of Excellence for Invasion Biology and A.S.D.S. acknowledge support from the South African National Biodiversity Institute for the SANSA project. Information on plant community composition and habitat structure was provided by Jelle Cattie (Wageningen University, the Netherlands). We thank Rudy Jocqué (Africa Museum, Tervuren, Belgium) and Charles Haddad (University of the Free State, Bloemfontein, South Africa) for discussions.

\section{REFERENCES}

BERGER, K., CRAFFORD, J.E., GAIGHER, I., GAIGHER, M.J., HAHN, N. \& MACDONALD, I. 2003, A First Synthesis of the Environmental, Biological \& Cultural Assets of the Soutpansberg. Leach Printers \& Signs, Louis Trichardt, South Africa.

BORGES, P.A.V. \& BROWN, V.K. 2004. Arthropod community structure in pastures of an island archipelago (Azores): looking for local-regional species richness patterns at fine-scales. Bulletin of Entomological Research 94: 111-121.

BOTES, A., McGEOCH, M.A., ROBERTSON, H.G., VAN NIEKERK, A., DAVIDS, H.P. \& CHOWN, S.L. 2006. Ants, altitude and change in the northern Cape Floristic Region. Journal of Biogeography 33: 71-90.

CLARKE, K.R. \& WARWICK, R.M. 2001. Change in Marine Communities: an Approach to Statistical Analysis and Interpretation, 2nd edn. PRIMER-E, Plymouth.

CLARKE, K.R. \& WARWICK, R.M. 1994. Change in Marine Communities: An Approach to Statistical Analysis and Interpretation. Natural Environmental Research Council, Plymouth, U.K.

COLEMAN, B.D. 1981. On random placement and species-area relations. Mathematical Biosciences 54: 191-215.

COLWELL, R.K. 1994-2004. Estimate S: Statistical estimation of species richness and shared species from samples. Version 7. Online at: www.purl.oclc.org/ estimates

COLWELL, R.K. \& CODDINGTON, J.A. 1994. Estimating terrestrial biodiversity through extrapolation. Philosophical Transactions of the Royal Society (Ser. B) 345: 101-118.

CORNELL, H.V. 1993. Unsaturated patterns in species assemblages: the role of regional processes in setting local species richness. In: Species Diversity in Ecological Communities. Historical and Geographical Perspectives, (eds) R.E. Ricklefs \& D. Schluter, pp. 243-255. University of Chicago Press, Chicago. 
DINIZ-FILHO, J.A.F., BINI, L.M. \& HAWKINS, B.A. 2003. Spatial autocorrelation and red herrings in geographical ecology. Global Ecology \& Biogeography 12: 53-64.

DIPPENAAR, S.M., DIPPENAAR-SCHOEMAN, A.S., MODIBA, M.A. \& KHOZA, T.T. 2008. A checklist of the spiders (Arachnida, Araneae) of the Polokwane Nature Reserve, Limpopo Province, South Africa. Koedoe 50: 10-17.

DIPPENAAR-SCHOEMAN, A.S. 2006. New records of 43 spider species from the Mountain Zebra National Park, South Africa (Arachnida: Araneae). Koedoe 49: 23-28.

DIPPENAAR-SCHOEMAN, A.S. \& LEROY, A. 2003. A check list of the spiders of the Kruger National Park, South Africa (Arachnida: Araneae). Koedoe 46: 91-100.

DIPPENAAR-SCHOEMAN, A.S., LEROY, A., DE JAGER, M. \& VAN DEN BERG, M.A. 1999. A check list of the spider fauna of the Karoo National Park, South Africa (Arachnida: Araneae). Koedoe 42: 31-42.

DIPPENAAR-SCHOEMAN, A.S. \& CRAEMER, C. 2000. The South African National Survey of Arachnida. Plant Protection News 56: 11-12.

DIPPENAAR-SCHOEMAN, A.S. \& HADDAD, C. 2006. South African National Survey of Arachnida. Newsletter No. 1: 1-9.

DIPPENAAR-SCHOEMAN, A.S. VAN DEN BERG, A.M. \& VAN DEN BERG, A. 1989. Species composition and relative seasonal abundance of spiders from the field and tree layers of the Roodeplaat Dam Nature Reserve. Koedoe 32: 25-38.

DIPPENAAR-SCHOEMAN, A.S., VAN DER WALT, A.E., DE JAGER, M., LE ROUX E. \& VAN DEN BERG, A. 2005. The spiders of the Swartberg Nature Reserve in South Africa (Arachnida: Araneae). Koedoe 48: 77-86.

DUFR NE, M. \& LEGENDRE, P. 1997. Species assemblages and indicator species: the need for a flexible asymmetrical approach. Ecological Monographs 67: 345-366.

EDWARDS, D. 1983, A broad scale structural classification of vegetation for practical purposes. Bothalia, 14: 705-712.

FLATHER, C.H., WILSON, K.R., DEAN, D.J. \& McCOMB, W.C. 1997. Identifying gaps in conservation networks: of indicators and uncertainty in geographic-based analyses. Ecological Applications 7: 531-542.

FOORD, S.H., DIPPENAAR-SCHOEMAN, A.S. \& VAN DER MERWE, M. 2002. A check list of the spider fauna of the Western Soutpansberg, South Africa (Arachnida: Araneae). Koedoe 45: 35-43.

FOORD, S.H. \& DIPPENAAR-SCHOEMAN, A.S. 2005. A revision of the Afrotropical species of Hersiliola Thorell and Tama Simon with description of a new genus Tyrotama (Araneae: Hersiliidae). African Entomology 13: 255-279.

GAIGHER, I.G. 2006. Lajuma Environmental Research Centre, Makhado (Louis Trichardt), South Africa. Online at: http://www.Lajuma.com

GOTELLI, N.J. \& COLWELL, R.K. 2001. Quantifying biodiversity: procedures and pitfalls in the measurement and comparison of species richness. Ecological Letters 4: 379-391.

GRISWOLD, C.E. 1987. A review of the southern African spiders of the family Cyatholipidae Simon, 1894 (Araneae: Araneomorphae). Annals of the Natal Museum 28: 499-542.

HADDAD, C.R., DIPPENAAR-SCHOEMAN, A.S. \& WESOLOWSKA, W. 2006. A checklist of the nonacarine arachnids (Chelicerata: Arachnida) of the Ndumo Game Reserve, Maputaland, South Africa. Koedoe 49: 1-22.

HADDAD, C.R., DIPPENAAR-SCHOEMAN, A.S. In press. A checklist of the non-acarine arachnids (Chelicerata: Arachnida) of the De Hoop Nature Reserve, Western Cape Province, South Africa. Koedoe.

HAHN, N. 2002. Endemic flora of the Soutpansberg. M.Sc. thesis, University of KwaZulu-Natal, Pietermaritzburg.

HAHN, N. 2006. Floristic diversity of the Soutpansberg, Limpopo Province, South Africa. Ph.D. thesis, University of Pretoria, Pretoria.

HUBER, B.A. Southern African pholcid spiders: revision and cladistic analysis of Quamtana gen. nov. and Spermaphora Hentz (Araneae: Pholcidae), with notes on male-female covariation. Zoological Journal of the Linnean Society 139: 477-527.

HURLBERT, S.H. 1984. Pseudoreplication and the design of ecological field experiments. Ecological Monographs 54: 187-211.

JIMÉNEZ-VALVERDE, A. \& LOBO, J.M. 2007. Determinants of local spider (Araneidae and Thomisidae) species richness on a regional scale: climate and altitude vs habitat structure. Ecological Entomology 32: 113-122.

JOCQUÉ, R. 1981. Reduced size of spiders in marginal habitats. Oecologia 49: 404-408.

JOCQUÉ, R. 2008. A new candidate for a Gondwanaland distribution in the Zodariidae (Araneae): Australutica in Africa. ZooKeys 1: 59-66.

JOCQUÉ, R. \& DIPPENAAR-SCHOEMAN, A.S. 2006. Spider Families of the World. Royal Museum for Central Africa, Tervuren.

KOENIG, W.D. 1999. Spatial autocorrelation of ecological phenomena. Trends in Ecology and Evolution 14: 22-26.

LEGENDRE, P. 1993. Spatial autocorrelation: Trouble or new paradigm? Ecology 74: 1659-1673.

LEPŠ, J. \& ŠMILAUER, P. 2003. Multivariate Analysis of Ecological Data using CANOCO. Cambridge University Press, Cambridge.

LIEDLOFF, A. 1999. Mantel non-parametric test calculator. Online at: http://www.sci.qut.edu.au/NRS/ Mantel.htm

LOTZ, L.N. 2003. Afrotropical Archaeidae: 2. New species of the genera Archaea and Afrarchaea (Arachnida: Araneae). Navorsinge van die Nasionale Museum Bloemfontein 19: 221-240.

MUCINA, L., RUTHERFORD, M.C. \& POWRIE, L.W. 2005. Vegetation Map of South Africa, Lesotho and Swaziland, 1:100 000 scale sheet maps. South African National Biodiversity Institute, Pretoria.

NEW, T.R. 1999. Untangling the web: spiders and the challenges of invertebrate conservation. Journal of Insect Conservation 3: 251-256.

PRENDINI, L. 2006. New South African flat rock scorpions (Liochelidae: Hadogenes). American Museum Novitates 3502: 1-32 
REYERS, B. 2003. Incorporating anthropogenic threats into evaluations of regional biodiversity and prioritisation of conservation areas in the Limpopo Province, South Africa. Biological Conservation 118: 521-531.

RICKLEFS, R.E. 1987. Community diversity: relative roles of local and regional processes. Science 235: 167-171.

RODRIGUES, A.S.L., TRATT, R., WHEELER, B.D. \& GASTON, K.J. 1999. The performance of existing networks of conservation areas in representing biodiversity. Proceeding of the Royal Society of London B 266: 1453-1460.

RYPSTRA, A.L. 1986. Web spiders in temperate and tropical forests: Relative abundance and environmental correlates. American Midland Naturalist 115: 42-51.

SCHARFF, N., CODDINGTON, J.A., GRISWOLD, C.E., HORMIGA, G. \& BJØRN, P.P. 2003. When to quit? Estimating spider species richness in a Northern European deciduous forest. Journal of Arachnology 31: 246-273.

SOUTHWOOD, T.R.E. \& HENDERSON, P.A. 2000. Ecological Methods, 3rd edn. Blackwell Science, Oxford.

TER BRAAK, C.J.F. \& ŠMILAUER, P. 2002. CANOCO Reference Manual and CanoDraw for Windows User's guide: Software for Canonical Community
Ordination (version 4.5). Microcomputer Power, Ithaca, New York.

TOTI, D.S., COYLE, F.A. \& MILLER, J.A. 2000. A structured inventory of Appalachian grass bald and heath bald spider assemblages and a test of species richness estimator performance. Journal of Arachnology 28: 329-345.

VAN WYK, A.E. \& SMITH, G.F. 2001. Regions of Floristic Endemism in Southern Africa. Umdaus Press, Pretoria.

UETZ, G.W. 1991. Habitat structure and spider foraging. In: Habitat Structure: The Physical Arrangement of Objects in Space, (eds) S.S. Bell, E.D. McCoy \& H.R. Mushinsky, pp. 325-348. Chapman and Hall, New York.

UNESCO. 2005. Biosphere Reserves: Benefits and Opportunities. UNESCO, Paris.

WHITMORE, C., SLOTOW, R., CROUCH, T.E. \& DIPPENAAR-SCHOEMAN, A.S. 2002. Diversity of spiders (Araneae) in a savanna reserve, Northern Province, South Africa. Journal of Arachnology 30: 344-356.

WIENS, J.A. 1989. Spatial scaling in ecology. Functional Ecology 3: 385-397.

WIS.E., D.H. 2005. Cannibalism, food limitation, intraspecific competition, and the regulation of spider populations. Annual Review of Entomology 51: 441-465.

Responsible Editor: C.L. Griffiths

Appendix 1. A checklist of the spiders (Araneae) of Lajuma Mountain Retreat. The density of genera is given for the whole assemblage, whereas species densities are given for the whole assemblage and for the habitats (abundances are given in brackets). Functional group: AOWB = adapted orb web; FGW = free-living ground wanderer; $B G W=$ burrrow-living ground wanderer; BPW = burrow-living plant wanderer; FPW = free living plant wanderer; burrow living plant wanderer; FWB = funnel web; RWB = retreat web; OWB = orb web; GWB = gumfoot web; SHWB = sheet web; SPWB = space web. Habitat abbreviations: MG = Mosaic Grassland; MW = Mosaic Woodland; SF = Short Forest; TF = Tall Forest; $\mathrm{W}=$ Woodland . Symbols: $\bullet$ indicates a new genus and species, $\dagger$ indicates a new species, $\ddagger$ a possible new species; all endemic taxa are indicated by grey arrowheads: \#\#, endemic, \#, near-endemic to the Soutpansberg. Foord et al. 2002 (p) lists the species recorded in that study, new records, post-2005, are also listed (p).

\begin{tabular}{|c|c|c|c|c|c|c|c|c|c|c|}
\hline \multirow[t]{2}{*}{ Family } & \multirow[t]{2}{*}{ Species/Functional group } & \multirow{2}{*}{$\begin{array}{l}\text { Foord } \\
\text { et al. } \\
2002\end{array}$} & \multirow{2}{*}{$\begin{array}{c}\text { New } \\
\text { records: } \\
\text { post- } \\
2005\end{array}$} & \multirow{2}{*}{ Genera } & \multirow[t]{2}{*}{ Spp. } & \multicolumn{5}{|c|}{ Vegetation type } \\
\hline & & & & & & MG & MW & SF & $\mathrm{TF}$ & W \\
\hline \multirow[t]{4}{*}{ Agelenidae } & Agelena australis (Simon, 1896)/FWB & $\mathrm{p}$ & & & & 5 & 2 & 0 & 0 & 7 \\
\hline & Benoitia ocellata (Pocock, 1900)/FWB & $\mathrm{p}$ & & & & 9 & 16 & 0 & 0 & 1 \\
\hline & Maimuna deserticola (Simon, 1910)/FWB & & $p$ & & & & & & & \\
\hline & Total & & & 2 & 2 & $2(14)$ & $2(18)$ & 0 & 0 & $2(8)$ \\
\hline \multirow[t]{2}{*}{ Amaurobiidae } & Pseudauximus annulatus Purcell, 1908/RWB & $p$ & & & & 0 & 0 & 0 & 7 & 1 \\
\hline & Total & & & 1 & 1 & 0 & 0 & 0 & $1(7)$ & $1(1)$ \\
\hline \multirow[t]{2}{*}{ Anapidae } & Metanapis bimaculata (Simon, 1895)/OWB & $\mathrm{p}$ & & & & 0 & 0 & 0 & 0 & 0 \\
\hline & Total & & & 0 & 0 & 0 & 0 & 0 & 0 & 0 \\
\hline \multirow[t]{8}{*}{ Araneidae } & - 'Acanthepeira'-like/OWB & 0 & & & & 0 & 1 & 9 & 1 & 0 \\
\hline & - Araneidae genus undetermined/OWB & 0 & & & & 0 & 1 & 15 & 3 & 0 \\
\hline & Araneilla sp.1/OWB & $p$ & & & & 35 & 4 & 3 & 1 & 14 \\
\hline & Araneus apricus (Karsch, 1884)/OWB & & $p$ & & & & & & & \\
\hline & $\begin{array}{l}\text { Araneus legonensis Grasshoff \& Edmund, } \\
\text { 1979/OWB }\end{array}$ & 0 & & & & 0 & 0 & 5 & 4 & 0 \\
\hline & Araneus nigroquadratus Lawrence, 1937/0WB & 0 & & & & 0 & 1 & 2 & 0 & 2 \\
\hline & Araneus sp.1/0WB & 0 & & & & 1 & 17 & 22 & 25 & 0 \\
\hline & $\ddagger$ Araneussp.2/0WB & 0 & & & & 0 & 0 & 0 & 1 & 0 \\
\hline
\end{tabular}




\begin{tabular}{|c|c|c|c|c|c|c|c|c|c|c|}
\hline \multirow[t]{2}{*}{ Family } & \multirow[t]{2}{*}{ Species/Functional group } & \multirow{2}{*}{$\begin{array}{l}\text { Foord } \\
\text { et al. } \\
2002\end{array}$} & \multirow{2}{*}{$\begin{array}{l}\text { New } \\
\text { records: } \\
\text { post- } \\
2005\end{array}$} & \multirow{2}{*}{ Genera } & \multirow[t]{2}{*}{ Spp. } & \multicolumn{5}{|c|}{ Vegetation type } \\
\hline & & & & & & $M G$ & MW & SF & TF & W \\
\hline & Araneus sp.3/0WB & 0 & & & & 1 & 1 & 1 & 0 & 1 \\
\hline & Araneus sp.4/OWB & 0 & & & & 2 & 1 & 0 & 1 & 0 \\
\hline & Araneus sp.5/OWB & 0 & & & & 0 & 0 & 1 & 0 & 0 \\
\hline & Araneus strupifera (Simon, 1885)/OWB & $\mathrm{p}$ & & & & 0 & 0 & 0 & 0 & 0 \\
\hline & Argiope lobata (Pallas, 1772)/OWB & 0 & & & & 1 & 0 & 0 & 0 & 0 \\
\hline & Caerostris sexcuspidata (Fabricius, 1793)/OWB & B p & & & & 0 & 3 & 7 & 19 & 3 \\
\hline & Chorizopes sp.1/OWB & 0 & & & & 0 & 0 & 0 & 0 & 2 \\
\hline & Cyclosa insulana (Costa 1834)/OWB & $\mathrm{p}$ & & & & 8 & 21 & 25 & 18 & 4 \\
\hline & Cyphalonotus larvatus (Simon, 1881)/OWB & p & & & & 0 & 3 & 3 & 0 & 8 \\
\hline & Cyrtophora citricola (Forskål, 1775)/OWB & p & & & & 0 & 1 & 0 & 0 & 0 \\
\hline & $\begin{array}{l}\text { Hypsosinga lithyphantoides Caporiacco, 1947/ } \\
\text { OWB }\end{array}$ & 0 & & & & 2 & 1 & 5 & 0 & 20 \\
\hline & Ideocaira sp.1/OWB & 0 & & & & 0 & 1 & 0 & 2 & 0 \\
\hline & Lipocrea longissima (Simon, 1881)/OWB & 0 & & & & 1 & 0 & 0 & 0 & 0 \\
\hline & Neoscona blondeli (Simon, 1885)/OWB & $\mathrm{p}$ & & & & 7 & 113 & 7 & 4 & 11 \\
\hline & Neoscona penicillipes (Karsch, 1879)/OWB & 0 & & & & 0 & 1 & 0 & 0 & 0 \\
\hline & Neoscona quincasea Roberts, 1983/OWB & $\mathrm{p}$ & & & & 1 & 14 & 6 & 0 & 9 \\
\hline & Neoscona subfusca (C.L. Koch, 1837)/OWB & $\mathrm{p}$ & & & & 1 & 27 & 11 & 6 & 20 \\
\hline & Neoscona triangula (Keyserling, 1864)/OWB & & $\mathrm{p}$ & & & & & & & \\
\hline & Pararaneus spectator (Karsch, 1886)/OWB & 0 & & & & 0 & 0 & 1 & 3 & 4 \\
\hline & Singa lawrencei (Lessert, 1930)/OWB & 0 & & & & 2 & 0 & 0 & 0 & 2 \\
\hline & Total & & & 18 & 28 & $13(65)$ & $18(212)$ & $17(127)$ & $15(108)$ & $14(101)$ \\
\hline \multirow[t]{2}{*}{ Caponiidae } & Caponia sp./FGW & $\mathrm{p}$ & & & & 0 & 2 & 2 & 1 & 2 \\
\hline & Total & & & 1 & 1 & 0 & $1(2)$ & $1(2)$ & $1(1)$ & $1(2)$ \\
\hline \multirow[t]{6}{*}{ Clubionidae } & Clubiona bevisi Lessert, 1923/FPW & 0 & & & & 0 & 18 & 2 & 12 & 5 \\
\hline & Clubiona godfreyi Lessert, 1921/FPW & 0 & & & & 1 & 121 & 227 & 179 & 61 \\
\hline & Clubiona lawrencei Roewer, 1951/FPW & $\mathrm{p}$ & & & & 0 & 0 & 0 & 0 & 0 \\
\hline & Clubiona pupillaris Lawrence, 1938/FPW & 0 & & & & 0 & 7 & 6 & 9 & 5 \\
\hline & Clubiona sp.1/FPW & $\mathrm{p}$ & & & & 0 & 4 & 0 & 0 & 0 \\
\hline & Total & & & 1 & 4 & $1(1)$ & $4(150)$ & $3(235)$ & $3(200)$ & $3(71)$ \\
\hline \multirow[t]{21}{*}{ Corinnidae } & Cambalida coriacea Simon, 1909/FGW & 0 & & & & 0 & 13 & 12 & 2 & 57 \\
\hline & Castianeira fulvipes Simon, 1896/FGW & $\mathrm{p}$ & & & & 0 & 0 & 0 & 0 & 0 \\
\hline & Cetonana simoni (Lawrence, 1942)/FGW & $\mathrm{p}$ & & & & 0 & 16 & 14 & 30 & 9 \\
\hline & Copa flavoplumosa Simon, 1885/FGW & 0 & & & & 0 & 23 & 16 & 13 & 23 \\
\hline & Copa sp.2/FGW & 0 & & & & 0 & 0 & 0 & 2 & 2 \\
\hline & Corinna natalis Pocock, 1898 & & $\mathrm{p}$ & & & & & & & \\
\hline & •\#\#Corinninae sp.1/FGW & 0 & & & & 8 & 4 & 1 & 0 & 0 \\
\hline & Corinnomma lawrencei Haddad, 2006/FGW & 0 & & & & 0 & 0 & 2 & 0 & 0 \\
\hline & Corinnomma radiata Haddad, 2006/FGW & 0 & $n$ & & & 0 & 0 & 2 & 0 & 0 \\
\hline & Graptartia tropicalis Haddad, 2004/FGW & 0 & $p$ & & & 0 & 6 & 3 & 0 & 1 \\
\hline & $\begin{array}{l}\text { \#\# Hortipes contubernalis Bosselaers \& } \\
\text { Jocqué, 2000/FGW }\end{array}$ & $\mathrm{p}$ & & & & 0 & 0 & 0 & 3 & 0 \\
\hline & †\#\#Hortipes sp. 4/FGW & 0 & & & & 0 & 0 & 0 & 1 & 0 \\
\hline & Merenius simoni Lessert, 1921/FGW & 0 & & & & 0 & 1 & 0 & 0 & 0 \\
\hline & Pronophaea sp.2/FGW & 0 & & & & 0 & 21 & 0 & 0 & 1 \\
\hline & Pronophaea natalica Simon, 1897/FGW & 0 & & & & 0 & 5 & 0 & 0 & 0 \\
\hline & $\begin{array}{l}\text { Thysanina transversa Lyle \& Haddad, 2006/ } \\
\text { FGW }\end{array}$ & 0 & & & & 0 & 1 & 3 & 5 & 1 \\
\hline & Trachelas sp.1/FGW & 0 & & & & 0 & 0 & 0 & 0 & 2 \\
\hline & Trachelas sp.2/FGW & 0 & & & & 0 & 1 & 0 & 0 & 3 \\
\hline & Trachelas sp.3/FGW & 0 & & & & 0 & 1 & 0 & 0 & 3 \\
\hline & Trachelinae sp.1 & $\mathrm{p}$ & & & & 0 & 0 & 0 & 0 & 0 \\
\hline & Total & & & 13 & 18 & 0 & 20 (119) & $13(52)$ & $13(56)$ & $17(103)$ \\
\hline \multirow[t]{2}{*}{ Ctenidae } & Ctenus transvaalensis Benoit, 1981/FGW & $\mathrm{p}$ & & & & 0 & 15 & 13 & 16 & 37 \\
\hline & Total & & & 2 & 3 & 0 & $2(21)$ & $2(25)$ & $2(22)$ & $3(51)$ \\
\hline \multirow[t]{3}{*}{ Cyrtaucheniidae } & Ancylotrypha nuda (Hewitt, 1916)/BGW & 0 & & & & 4 & 0 & 0 & 2 & 1 \\
\hline & Homostola pardalina (Hewitt, 1913)/BGW & $\mathrm{p}$ & & & & 0 & 0 & 0 & 2 & 0 \\
\hline & Total & & & 2 & 2 & $1(4)$ & 0 & 0 & $2(4)$ & $1(1)$ \\
\hline
\end{tabular}




\begin{tabular}{|c|c|c|c|c|c|c|c|c|c|c|}
\hline \multirow[t]{2}{*}{ Family } & \multirow[t]{2}{*}{ Species/Functional group } & \multirow{2}{*}{$\begin{array}{l}\text { Foord } \\
\text { et al. } \\
2002\end{array}$} & \multirow{2}{*}{$\begin{array}{c}\text { New } \\
\text { records: } \\
\text { post- } \\
2005\end{array}$} & \multirow{2}{*}{ Genera } & \multirow[t]{2}{*}{ Spp. } & \multicolumn{5}{|c|}{ Vegetation type } \\
\hline & & & & & & $M G$ & MW & SF & TF & W \\
\hline \multirow[t]{3}{*}{ Deinopidae } & Deinopis cornigera Gerstäecker, 1873/AOWB & $\mathrm{p}$ & & & & 1 & 0 & 0 & 1 & 1 \\
\hline & Menneus camelus Pocock, 1902 /AOWB & 0 & & & & 0 & 11 & 16 & 16 & 7 \\
\hline & Total & & & 2 & 2 & $1(1)$ & $1(11)$ & $1(16)$ & $1(17)$ & $1(8)$ \\
\hline \multirow[t]{3}{*}{ Dictynidae } & Devade sp.1/RWB & $\mathrm{p}$ & & & & 0 & 0 & 1 & 6 & 1 \\
\hline & Mashimo leleupi Lehtinen, 1967/RWB & 0 & & & & 0 & 1 & 0 & 0 & 0 \\
\hline & Total & & & 1 & 1 & 0 & $1(1)$ & $1(1)$ & $1(6)$ & $1(1)$ \\
\hline \multirow[t]{3}{*}{ Eresidae } & Dresserus colsoni Tucker, 1920/RWB & 0 & & & & 0 & 3 & 3 & 3 & 5 \\
\hline & Penestomus sp. (immature)/FPW & $\mathrm{p}$ & & & & 0 & 0 & 0 & 0 & 0 \\
\hline & Total & & & 2 & 1 & 0 & $1(3)$ & $1(3)$ & $1(3)$ & $1(5)$ \\
\hline \multirow[t]{21}{*}{ Gnaphosidae } & Aneplasa sp.1 & & & & & & & & & \\
\hline & Aphantaulax inornata Tucker, 1923/FGW & $\mathrm{p}$ & & & & 0 & 0 & 0 & 0 & 0 \\
\hline & Asemesthes numisma Tucker, 1923/FGW & $\mathrm{p}$ & & & & 2 & 7 & 0 & 0 & 9 \\
\hline & Asemesthes payntei Tucker, 1923/FGW & 0 & & & & 4 & 0 & 0 & 0 & 18 \\
\hline & Camillina cordifera (Tullgren, 1910)/FGW & 0 & & & & 0 & 7 & 1 & 2 & 46 \\
\hline & Drassodes sp.12/FGW & $\mathrm{p}$ & & & & 3 & 0 & 0 & 1 & 0 \\
\hline & Drassodinae sp.4/FGW & 0 & & & & 0 & 28 & 7 & 4 & 39 \\
\hline & Echeminae sp.10/FGW & 0 & & & & 0 & 5 & 1 & 0 & 13 \\
\hline & Echeminae sp.8/FGW & 0 & & & & 1 & 3 & 0 & 2 & 8 \\
\hline & Echeminae sp.9/FGW & 0 & & & & 0 & 1 & 2 & 0 & 6 \\
\hline & Echemus erutus Tucker, 1923/FGW & $\mathrm{p}$ & & & & 0 & 0 & 0 & 0 & 0 \\
\hline & $\begin{array}{l}\text { Megamyrmekion transvaalense Tucker, 1923/ } \\
\text { FGW }\end{array}$ & $\mathrm{p}$ & & & & 0 & 0 & 0 & 0 & 0 \\
\hline & Setaphis arcus Tucker, 1923/FGW & $\mathrm{p}$ & & & & 0 & 0 & 0 & 1 & 3 \\
\hline & Setaphis subtilis (Simon, 1897)/FGW & 0 & & & & 0 & 6 & 1 & 0 & 5 \\
\hline & $\begin{array}{l}\text { Trachyzelotes jaxartensis (Kronenberg, 1875/ } \\
\text { FGW }\end{array}$ & 0 & & & & 0 & 1 & 0 & 0 & 0 \\
\hline & Xerophaeus sp./FGW & $\mathrm{p}$ & & & & 0 & 0 & 0 & 0 & 0 \\
\hline & Zelotes hewitti Tucker, 1923/FGW & 0 & & & & 0 & 17 & 5 & 1 & 43 \\
\hline & Zelotes tuckeri Roewer, 1951/FGW & $\mathrm{p}$ & & & & 0 & 0 & 0 & 0 & 0 \\
\hline & Zelotes ungulus Tucker, 1923/FGW & 0 & & & & 1 & 2 & 4 & 1 & 8 \\
\hline & Zelotes sp.7/FGW & 0 & & & & 2 & 6 & 1 & 0 & 4 \\
\hline & Total & & & 10 & 14 & $6(13)$ & $11(86)$ & $8(25)$ & $7(15)$ & $12(207)$ \\
\hline \multirow[t]{2}{*}{ Hahniidae } & Hahnia tabulicola Simon, 1898/SPWB & $\mathrm{p}$ & & & & 0 & 2 & 0 & 0 & 1 \\
\hline & Total & & & 1 & 1 & 0 & $1(2)$ & 0 & 0 & $1(1)$ \\
\hline \multirow[t]{2}{*}{ Idiopidae } & Idiops castaneus Hewitt, 1913/BGW & $\mathrm{p}$ & & & & 0 & 0 & 0 & 0 & 0 \\
\hline & Total & & & 0 & 0 & 0 & 0 & 0 & 0 & 0 \\
\hline \multirow[t]{12}{*}{ Linyphiidae } & Linyphiidae sp.1/SHWB & 0 & & & & 3 & 29 & 88 & 40 & 368 \\
\hline & Linyphiidae sp.2/SHWB & 0 & & & & 1 & 25 & 22 & 13 & 18 \\
\hline & ‡ Linyphiidae sp.4/SHWB & 0 & & & & 0 & 1 & 0 & 0 & 0 \\
\hline & Linyphiidae sp.5/SHWB & 0 & & & & 0 & 0 & 75 & 2 & 3 \\
\hline & Linyphiidae sp.7/SHWB & 0 & & & & 0 & 0 & 0 & 0 & 1 \\
\hline & Linyphiidae genus_A sp. & $\mathrm{p}$ & & & & 0 & 0 & 0 & 0 & 0 \\
\hline & Linyphiidae genus_B sp. & $\mathrm{p}$ & & & & 0 & 0 & 0 & 0 & 0 \\
\hline & Mecynidis sp.3/SHWB & 0 & & & & 0 & 10 & 12 & 15 & 12 \\
\hline & Microlinyphia sp.6/SHWB & 0 & & & & 0 & 1 & 0 & 0 & 0 \\
\hline & Microlinyphia sterilis (Pavesi, 1883)/SHWB & $\mathrm{p}$ & & & & 0 & 0 & 0 & 0 & 0 \\
\hline & $\begin{array}{l}\text { Neriene natalensis Van Helsdingen, 1970/ } \\
\text { SHWB }\end{array}$ & $\mathrm{p}$ & & & & 0 & 0 & 0 & 0 & 0 \\
\hline & Total & & & 2 & 7 & $2(4)$ & $5(68)$ & $4(197)$ & $4(70) 5$ & $5(409)$ \\
\hline \multirow[t]{8}{*}{ Lycosidae } & Lycosidae sp.4/FGW & 0 & & & & 1 & 20 & 9 & 4 & 8 \\
\hline & Lycosidae sp.7/FGW & 0 & & & & 1 & 0 & 0 & 0 & 0 \\
\hline & $\begin{array}{l}\text { ¥ Minicosa neptuna Alderweireldt \& Jocqué, } \\
2007 / \text { FGW }\end{array}$ & 0 & & & & 0 & 0 & 0 & 0 & 1 \\
\hline & Pardosa crassipalpis Purcell, 1903/FGW & $\mathrm{p}$ & & & & 0 & 0 & 2 & 0 & 0 \\
\hline & Pardosa leipoldti Purcell, 1903/FGW & $\mathrm{p}$ & & & & 0 & 35 & 23 & 37 & 7 \\
\hline & Pardosa umtalica Purcell, 1903/FGW & 0 & & & & 0 & 0 & 1 & 0 & 1 \\
\hline & Proevippa albiventris (Simon, 1898)/FGW & 0 & & & & 1 & 287 & 296 & 199 & 106 \\
\hline & Proevippa fascicularis (Purcell, 1903)/FGW & $\mathrm{p}$ & & & & 0 & 0 & 3 & 0 & 2 \\
\hline
\end{tabular}




\begin{tabular}{|c|c|c|c|c|c|c|c|c|c|c|}
\hline \multirow[t]{2}{*}{ Family } & \multirow[t]{2}{*}{ Species/Functional group } & \multirow{2}{*}{$\begin{array}{l}\text { Foord } \\
\text { et al. } \\
2002\end{array}$} & \multirow{2}{*}{$\begin{array}{l}\text { New } \\
\text { records: } \\
\text { post- } \\
2005\end{array}$} & \multirow{2}{*}{ Genera } & \multirow[t]{2}{*}{ Spp. } & \multicolumn{5}{|c|}{ Vegetation type } \\
\hline & & & & & & MG & MW & SF & TF & W \\
\hline & $\begin{array}{l}\text { Proevippa wanlessi (Russell-Smith, 1981)/ } \\
\text { FGW }\end{array}$ & $\mathrm{p}$ & & & & 4 & 20 & 22 & 9 & 8 \\
\hline & Trabea heteroculata Strand, 1913/FGW & 0 & & & & 2 & 89 & 93 & 88 & 16 \\
\hline & Trabea purcelli Roewer, 1951/FGW & 0 & & & & 0 & 1 & 1 & 0 & 0 \\
\hline & Total & & & 5 & 11 & $5(9)$ & $6(452)$ & $9(450)$ & $5(337)$ & $8(149)$ \\
\hline \multirow[t]{2}{*}{ Migidae } & †\#\#Poecilomigas sp.1/BPW & $\mathrm{p}$ & & & & 0 & 0 & 0 & 1 & 0 \\
\hline & Total & & & 1 & 1 & 0 & 0 & 0 & $1(1)$ & 0 \\
\hline \multirow[t]{4}{*}{ Mimetidae } & Ero sp.2/FPW & 0 & & & & 0 & 0 & 0 & 0 & 2 \\
\hline & $\ddagger$ Mimetus sp./FPW & $\mathrm{p}$ & & & & 0 & 0 & 0 & 0 & 0 \\
\hline & Mimetus cornutus Lawrence, 1947/FPW & 0 & & & & 0 & 0 & 29 & 0 & 1 \\
\hline & Total & & & 2 & 2 & 0 & 0 & $1(29)$ & 0 & $2(3)$ \\
\hline \multirow[t]{7}{*}{ Miturgidae } & Cheiracanthium africanum Lessert, 1921/FPW & $\mathrm{p}$ & & & & 3 & 10 & 2 & 0 & 24 \\
\hline & Cheiracanthium furculatum Karsch, 1879/FPW & 0 & & & & 0 & 2 & 0 & 0 & 0 \\
\hline & Cheiracanthium vansoni Lawrence, 1936/FPW & 0 & & & & 0 & 0 & 0 & 0 & 2 \\
\hline & Cheiramiona clavigera (Simon, 1897)/FPW & 0 & & & & 0 & 10 & 9 & 7 & 39 \\
\hline & Cheiramiona lajuma Lotz, 2002/FPW & $\mathrm{p}$ & & & & 1 & 24 & 36 & 19 & 124 \\
\hline & Cheiramiona krugerensis Lotz, 2002/FPW & 0 & & & & 0 & 0 & 0 & 0 & 2 \\
\hline & Total & & & 2 & 7 & $2(4)$ & $4(36)$ & $3(49)$ & $2(26) 5$ & $5(191)$ \\
\hline \multirow[t]{2}{*}{ Mysmenidae } & Undetermined sp. & $\mathrm{p}$ & & & & 0 & 0 & 0 & 0 & 0 \\
\hline & Total & & & 0 & 0 & 0 & 0 & 0 & 0 & 0 \\
\hline \multirow[t]{3}{*}{ Nemesiidae } & \#\# Entypesa schoutedeni Benoit, 1965/BPW & $\mathrm{p}$ & & & & 0 & 0 & 2 & 13 & 4 \\
\hline & Hermacha mazoena Hewitt, 1915/BPW & 0 & & & & 0 & 2 & 0 & 18 & 0 \\
\hline & Total & & & 2 & 2 & 0 & $1(2)$ & $1(2)$ & $2(31)$ & $1(4)$ \\
\hline \multirow[t]{3}{*}{ Nephiliidae } & Nephila fenestrata Thorell, 1859/OWB & $\mathrm{p}$ & & & & 0 & 0 & 2 & 69 & 3 \\
\hline & Nephila senegalensis (Walckenaer, 1842)/OWB & 0 & & & & 0 & 1 & 0 & 13 & 0 \\
\hline & Total & & & 2 & 2 & 0 & $1(1)$ & $1(2)$ & $2(82)$ & $1(3)$ \\
\hline \multirow[t]{2}{*}{ Oecobiidae } & $\begin{array}{l}\text { Uroecobius ecribellatus Kullman \& Zimmerman, } \\
\text { 1976/RWB }\end{array}$ & , p & & & & 0 & 0 & 0 & 0 & 0 \\
\hline & Total & & & 0 & 0 & 0 & 0 & 0 & 0 & 0 \\
\hline \multirow[t]{3}{*}{ Oonopidae } & Gamasomorpha sp.1 & 0 & & & & 0 & 5 & 26 & 10 & 31 \\
\hline & Opopaea sp. & & $\mathrm{p}$ & & & & & & & \\
\hline & Total & & & 1 & 1 & 0 & $1(5)$ & $1(26)$ & $1(10)$ & $1(31)$ \\
\hline \multirow[t]{2}{*}{ Orsolobidae } & Afrilobus sp.1 & 0 & & & & 0 & 1 & 0 & 0 & 0 \\
\hline & Total & & & 1 & 1 & 0 & $1(1)$ & 0 & 0 & 0 \\
\hline \multirow[t]{16}{*}{ Oxyopidae } & Hamataliwa fronticornis (Lessert, 1927)/FPW & 0 & & & & 0 & 3 & 4 & 0 & 5 \\
\hline & Hamataliwa kulczynskii (Lessert, 1915)/FPW & $\mathrm{p}$ & & & & 0 & 0 & 1 & 0 & 0 \\
\hline & Oxyopes bedoti Lessert, 1915/FPW & 0 & & & & 1 & 17 & 7 & 0 & 41 \\
\hline & Oxyopes bothai Lessert, 1915/FPW & & $\mathrm{p}$ & & & & & & & \\
\hline & Oxyopes hoggi Lessert, 1915/FPW & 0 & & & & 2 & 1 & 1 & 0 & 21 \\
\hline & Oxyopes jacksoni Lessert, 1915/FPW & $\mathrm{p}$ & & & & 3 & 0 & 0 & 0 & 16 \\
\hline & Oxyopes Iongispinosus Lawrence, 1938/FPW & $\mathrm{p}$ & & & & 1 & 5 & 3 & 9 & 21 \\
\hline & Oxyopes pallidecoloratus Strand, 1906/FPW & $\mathrm{p}$ & & & & 0 & 7 & 0 & 0 & 8 \\
\hline & Oxyopes russoi Caporiacco, 1940/FPW & 0 & & & & 6 & 7 & 1 & 1 & 38 \\
\hline & Oxyopes schenkeli Lessert, 1927/FPW & 0 & & & & 1 & 0 & 0 & 1 & 9 \\
\hline & Oxyopes sp.3/FPW & 0 & & & & 0 & 1 & 0 & 0 & 1 \\
\hline & Oxyopes sp.5/FPW & 0 & & & & 1 & 0 & 0 & 0 & 0 \\
\hline & Oxyopes sp.11/FPW & 0 & & & & 0 & 1 & 1 & 0 & 0 \\
\hline & Oxyopes sp.12/FPW & 0 & & & & 1 & 0 & 0 & 0 & 0 \\
\hline & Peucetia viridis (Blackwall, 1858)/FPW & $\mathrm{p}$ & & & & 0 & 4 & 1 & 0 & 6 \\
\hline & Total & & & 3 & 14 & $8(16)$ & $9(46)$ & $8(19)$ & $3(11)$ & $10(166)$ \\
\hline Palpimanidae & Palpimanus transvaalicus Simon, 1893/FGW & $p$ & & & & 1 & 6 & 18 & 8 & 10 \\
\hline & Total & & & 1 & 1 & $1(1)$ & $1(6)$ & $1(18)$ & $1(8)$ & $1(10)$ \\
\hline Philodromidae & Gephyrota sp.3/FGW & 0 & & & & 0 & 0 & 0 & 0 & 1 \\
\hline & Philodromus browningi Lawrence, 1952/FGW & $\mathrm{p}$ & & & & 1 & 33 & 3 & 1 & 61 \\
\hline
\end{tabular}




\begin{tabular}{|c|c|c|c|c|c|c|c|c|c|c|}
\hline \multirow[t]{2}{*}{ Family } & \multirow[t]{2}{*}{ Species/Functional group } & \multirow{2}{*}{$\begin{array}{l}\text { Foord } \\
\text { et al. } \\
2002\end{array}$} & \multirow{2}{*}{$\begin{array}{l}\text { New } \\
\text { records: } \\
\text { post- } \\
2005\end{array}$} & \multirow{2}{*}{ Genera } & \multirow[t]{2}{*}{ Spp. } & \multicolumn{5}{|c|}{ Vegetation type } \\
\hline & & & & & & $M G$ & MW & SF & TF & W \\
\hline & Philodromus guineensis Millot, 1941/FGW & 0 & & & & 2 & 44 & 14 & 2 & 51 \\
\hline & Suemus punctatus Lawrence, 1938/FGW & $\mathrm{p}$ & & & & 0 & 3 & 0 & 0 & 2 \\
\hline & Tibellus minor Lessert, 1919/FGW & $\mathrm{p}$ & & & & 0 & 0 & 0 & 0 & 14 \\
\hline & $\begin{array}{l}\text { Tibellus sunetae Van den Berg \& } \\
\text { Dippenaar-Schoeman, 1994/FGW }\end{array}$ & 0 & & & & 0 & 2 & 0 & 0 & 11 \\
\hline & Total & & & 4 & 6 & $2(3)$ & $4(88)$ & $2(35)$ & $2(11)$ & $6(150)$ \\
\hline \multirow[t]{9}{*}{ Pholcidae } & $\ddagger$ Micropholcus sp.1/SPWB & $\mathrm{p}$ & & & & 0 & 0 & 0 & 0 & 0 \\
\hline & Pholcus ciliatus Lawrence, 1938/SPWB & $\mathrm{p}$ & & & & 0 & 0 & 0 & 0 & 0 \\
\hline & Quamtana bonamanzi Huber, 2003/SPWB & 0 & & & & 0 & 5 & 10 & 158 & 24 \\
\hline & \# Quamtana entabeni Huber, 2003/SPWB & 0 & & & & 0 & 0 & 4 & 6 & 0 \\
\hline & \#\# Quamtana lajuma Huber, 2003/SPWB & 0 & & & & 0 & 0 & 0 & 2 & 2 \\
\hline & $\begin{array}{l}\text { Smeringopus natalensis Lawrence, 1947/ } \\
\text { SPWB }\end{array}$ & $\mathrm{p}$ & & & & 0 & 0 & 0 & 0 & 0 \\
\hline & Smeringopus sp.1/SPWB & 0 & & & & 2 & 2 & 1 & 4 & 1 \\
\hline & $\begin{array}{l}\text { Spermophora peninsulae Lawrence, 1964/ } \\
\text { SPWB }\end{array}$ & $\mathrm{p}$ & & & & 0 & 0 & 0 & 0 & 0 \\
\hline & Total & & & 2 & 4 & $1(2)$ & $2(7)$ & $3(15)$ & $4(170)$ & $3(27)$ \\
\hline \multirow[t]{2}{*}{ Phyxelididae } & Vidole sothoana Griswold, 1990/RWB & $\mathrm{p}$ & & & & 0 & 0 & 5 & 0 & 0 \\
\hline & Total & & & 1 & 1 & 0 & 0 & $1(5)$ & 0 & 0 \\
\hline \multirow[t]{4}{*}{ Pisauridae } & Afropisaura rothiformis (Strand, 1908)/FWB & 0 & & & & 3 & 1 & 3 & 1 & 6 \\
\hline & Cispius problematicus Blandin, 1978/FPW & $\mathrm{p}$ & & & & 0 & 0 & 0 & 0 & 0 \\
\hline & $\begin{array}{l}\text { Euprosthenopsis pulchella (Pocock, 1902)/ } \\
\text { FWB }\end{array}$ & $\mathrm{p}$ & & & & 0 & 0 & 0 & 0 & 0 \\
\hline & Total & & & 1 & 1 & $1(3)$ & $1(1)$ & $1(8)$ & $1(1)$ & $1(6)$ \\
\hline \multirow[t]{3}{*}{ Prodidomidae } & Austrodomus sp.1/FGW & $\mathrm{p}$ & & & & 0 & 0 & 0 & 0 & 0 \\
\hline & Theuma purcelli Tucker, 1923/FGW & $\mathrm{p}$ & & & & 0 & 0 & 0 & 1 & 2 \\
\hline & Total & & & 1 & 1 & 0 & 0 & 0 & $1(1)$ & $1(2)$ \\
\hline \multirow[t]{31}{*}{ Salticidae } & Aelurillus sp.1 & 0 & & & & 2 & 0 & 2 & 0 & 2 \\
\hline & Asemonea serrata Wesolowska, 2001 & 0 & & & & 0 & 0 & 1 & 0 & 0 \\
\hline & Asemonea sp.1 & 0 & & & & 0 & 0 & 7 & 18 & 0 \\
\hline & Baryphas ahenus Simon, 1902 & 0 & & & & 9 & 7 & 12 & 2 & 27 \\
\hline & Brancus bevisi Lessert, 1925 & $\mathrm{p}$ & & & & 0 & 1 & 0 & 0 & 1 \\
\hline & Cosmophasis australis Simon, 1902 & $\mathrm{p}$ & & & & 0 & 0 & 0 & 0 & 2 \\
\hline & Cosmophasis sp.2 & 0 & & & & 0 & 0 & 0 & 0 & 2 \\
\hline & Dendryphantes sp.1 & 0 & & & & 1 & 2 & 6 & 7 & 2 \\
\hline & Festucula sp. (immature) & $\mathrm{p}$ & & & & 0 & 0 & 0 & 0 & 0 \\
\hline & Heliophanus debilis Simon, 1901 & 0 & & & & 15 & 2 & 4 & 8 & 18 \\
\hline & Heliophanus lesserti Wesolowska, 1986 & & $p$ & & & & & & & \\
\hline & Heliophanus orchestra Simon, 1885 & $\mathrm{p}$ & & & & 0 & 1 & 3 & 4 & 1 \\
\hline & Hyllus argyrotoxus Simon, 1902 & & $\mathrm{p}$ & & & & & & & \\
\hline & Hyllus treleaveni Peckham \& Peckham, 1902 & 0 & & & & 1 & 4 & 0 & 1 & 27 \\
\hline & Langona sp.1 & & $\mathrm{p}$ & & & & & & & \\
\hline & Marpissa sp.1 & 0 & & & & 0 & 1 & 0 & 0 & 3 \\
\hline & Myrmarachne ichneumon Simon, 1886 & 0 & & & & 0 & 0 & 3 & 2 & 0 \\
\hline & $\begin{array}{l}\text { Myrmarachne marshalli Peckham \& Peckham, } \\
1903\end{array}$ & 0 & & & & 0 & 0 & 0 & 0 & 3 \\
\hline & Myrmarachne sp.1 & 0 & & & & 2 & 8 & 0 & 3 & 12 \\
\hline & Natta horizontalis Karsch, 1879 & $\mathrm{p}$ & & & & 0 & 0 & 0 & 0 & 0 \\
\hline & Pachyballus sp.1 & & $\mathrm{p}$ & & & & & & & \\
\hline & Pachyballus transversus Simon, 1900 & $\mathrm{p}$ & & & & 0 & 0 & 0 & 0 & 0 \\
\hline & Phlegra sp.1 & 0 & & & & 0 & 1 & 5 & 29 & 4 \\
\hline & Portia sp.1 & 0 & & & & 0 & 6 & 25 & 1 & 20 \\
\hline & Rhene machadoi Berland \& Millot, 1941 & 0 & & & & 1 & 0 & 0 & 0 & 2 \\
\hline & Salticidae (undetermined genus) sp.3 & 0 & & & & 0 & 0 & 1 & 0 & 0 \\
\hline & Stenaelurillus sp.1 & $\mathrm{p}$ & & & & 3 & 0 & 0 & 0 & 2 \\
\hline & Thyene coccineovittata (Simon, 1885) & 0 & & & & 8 & 13 & 5 & 4 & 12 \\
\hline & Thyene dakarensis Lawrence, 1927 & 0 & & & & 2 & 0 & 0 & 0 & 1 \\
\hline & Thyene inflata (Gerstaecker. 1875) & $p$ & & & & 5 & 2 & 1 & 21 & 5 \\
\hline & Thyene natalii (Peckham \& Peckham, 1903) & 0 & & & & 0 & 3 & 8 & 0 & 7 \\
\hline
\end{tabular}




\begin{tabular}{|c|c|c|c|c|c|c|c|c|c|c|}
\hline \multirow[t]{2}{*}{ Family } & \multirow[t]{2}{*}{ Species/Functional group } & \multirow{2}{*}{$\begin{array}{l}\text { Foord } \\
\text { et al. } \\
2002\end{array}$} & \multirow{2}{*}{$\begin{array}{l}\text { New } \\
\text { records: } \\
\text { post- } \\
2005\end{array}$} & \multirow{2}{*}{ Genera } & \multirow[t]{2}{*}{ Spp. } & \multicolumn{5}{|c|}{ Vegetation type } \\
\hline & & & & & & MG & MW & SF & TF & W \\
\hline & $\begin{array}{l}\text { Thyenula aurantiaca (Simon, 1902) } \\
\text { Thyenula sempiterna Wesolowska, } 2000\end{array}$ & $\mathrm{p}$ & $\mathrm{p}$ & & & 28 & 31 & 49 & 15 & 110 \\
\hline & Total & & & 19 & 27 & $13(81)$ & $16(99)$ & $17(157)$ & $15(171)$ & $23(290)$ \\
\hline \multirow[t]{6}{*}{ Scytodidae } & Scytodes clavata Benoit, 1965/FGW & 0 & & & & 0 & 0 & 16 & 105 & 1 \\
\hline & Scytodes fusca Walckenaer, 1837/FGW & $\mathrm{p}$ & & & & 0 & 0 & 0 & 0 & 0 \\
\hline & Scytodes maritima Lawrence, 1938/FGW & 0 & & & & 0 & 0 & 1 & 9 & 0 \\
\hline & Scytodes sp.1/FGW & $\mathrm{p}$ & & & & 0 & 0 & 0 & 0 & 0 \\
\hline & Scytodes sp.2/FGW & 0 & & & & 0 & 0 & 4 & 0 & 4 \\
\hline & Total & & & 1 & 4 & 0 & 0 & $4(21)$ & $3(114)$ & $2(5)$ \\
\hline \multirow[t]{2}{*}{ Segestriidae } & Ariadna sp.1/RWB & 0 & & & & 1 & 1 & 1 & 1 & 2 \\
\hline & Total & & & 1 & 1 & $1(1)$ & $1(1)$ & $1(1)$ & $1(1)$ & $1(2)$ \\
\hline \multirow[t]{5}{*}{ Selenopidae } & Anyphops sp.1/FGW & 0 & & & & 1 & 0 & 4 & 83 & 2 \\
\hline & $\begin{array}{l}\text { Selenops brachycephalus Lawrence, 1940/ } \\
\text { FGW }\end{array}$ & $p$ & & & & 0 & 0 & 10 & 163 & 1 \\
\hline & Selenops tenebrosus Lawrence, 1940/FGW & $\mathrm{p}$ & & & & 0 & 0 & 0 & 0 & 0 \\
\hline & Selenops zuluanus Lawrence, 1940/FGW & $\mathrm{p}$ & & & & 0 & 0 & 0 & 0 & 0 \\
\hline & Total & & & 2 & 3 & $1(2)$ & $1(1)$ & $2(15)$ & $3(247)$ & $2(5)$ \\
\hline \multirow[t]{2}{*}{ Sicariidae } & $\begin{array}{l}\text { Loxosceles spiniceps Lawrence, 1952/FGW } \\
\text { Sicarius sp.1 }\end{array}$ & $\mathrm{p}$ & & & & 0 & 0 & 0 & 2 & 0 \\
\hline & Total & & & 1 & 1 & 0 & 0 & 0 & $1(2)$ & 0 \\
\hline \multirow[t]{5}{*}{ Sparassidae } & Olios sp.1/FPW & 0 & & & & 0 & 0 & 2 & 0 & 5 \\
\hline & Olios sp.2/FPW & 0 & & & & 0 & 1 & 0 & 0 & 4 \\
\hline & Olios sp.3/FPW & 0 & & & & 0 & 3 & 0 & 0 & 3 \\
\hline & Palystes johnstoni Pocock, 1896/FPW & $p$ & & & & 0 & 0 & 0 & 1 & 0 \\
\hline & Total & & & 2 & 4 & 0 & $2(4)$ & $1(2)$ & $1(3)$ & $3(12)$ \\
\hline \multicolumn{11}{|l|}{ Tetragnathidae } \\
\hline & Leucauge decorata (Blackwall, 1864)/OWB & & $\mathrm{p}$ & & & & & & & \\
\hline & Leucauge festiva (Blackwall, 1866)/OWB & $\mathrm{p}$ & & & & 1 & 0 & 1 & 0 & 0 \\
\hline & Leucauge levanderi (Kulczynski, 1901)/OWB & & $\mathrm{p}$ & & & & & & & \\
\hline & Leucauge thomeensis Kraus, 1960/OWB & 0 & & & & 0 & 0 & 9 & 77 & 1 \\
\hline & Pachygnatha sp.1 & & $\mathrm{p}$ & & & & & & & \\
\hline & Tetragnatha subsquamata Okuma, 1985/0WB & 0 & & & & 0 & 0 & 9 & 49 & 0 \\
\hline & Total & & & 6 & 7 & $2(2)$ & $1(5)$ & $5(69)$ & $4(401)$ & ) $2(5)$ \\
\hline \multirow[t]{22}{*}{ Theraphosidae } & Ceratogyrus bechuanicus Purcell, 1902/BGW & $\mathrm{p}$ & & & & 0 & 0 & 0 & 0 & 0 \\
\hline & Harpactirella flavipilosa Lawrence,1936/BGW & $\mathrm{p}$ & & & & 0 & 1 & 0 & 0 & 0 \\
\hline & Harpactira sp.1 & & $\mathrm{p}$ & & & & & & & \\
\hline & Total & & & 1 & 1 & 0 & $1(1)$ & 0 & 0 & 0 \\
\hline & Argyrodes sp.1/GWB & 0 & & & & 0 & 1 & 13 & 13 & 0 \\
\hline & $\begin{array}{l}\text { Argyrodes sp.2/GWB }=\text { Rhomphaea nasica } \\
\quad(\text { Simon, 1873) }\end{array}$ & 0 & & & & 2 & 4 & 11 & 8 & 4 \\
\hline & Chrysso sp.10/GWB & 0 & & & & 0 & 0 & 0 & 1 & 0 \\
\hline & Coleosoma sp.1/GWB & 0 & & & & 0 & 1 & 3 & 17 & 4 \\
\hline & Coscinida ??sp. 1/GWB & 0 & & & & 0 & 0 & 0 & 2 & 2 \\
\hline & Coscinida tibialis Simon, 1895/GWB & $\mathrm{p}$ & & & & 1 & 6 & 8 & 15 & 0 \\
\hline & Crustulina sp.1/GWB & $\mathrm{p}$ & & & & 0 & 0 & 0 & 0 & 0 \\
\hline & Dipoena sp.4/GWB & 0 & & & & 0 & 0 & 0 & 3 & 1 \\
\hline & Dipoena sp.7/GWB & 0 & & & & 5 & 6 & 32 & 32 & 4 \\
\hline & Dipoenura sp.1/GWB & 0 & & & & 0 & 0 & 0 & 0 & 5 \\
\hline & Euryopis sp.4/GWB & 0 & & & & 0 & 0 & 0 & 0 & 9 \\
\hline & Euryopis sp.5/GWB & 0 & & & & 0 & 0 & 8 & 2 & 8 \\
\hline & Latrodectus geometricus C.L.Koch, 1841/GWB & $\mathrm{p}$ & & & & 0 & 0 & 0 & 0 & 0 \\
\hline & $\begin{array}{l}\text { Latrodectus renovulvatus Dahl, } 1902 \\
\text { Phoroncidia sp.2/GWB }\end{array}$ & 0 & $p$ & & & 0 & 0 & 0 & 1 & 2 \\
\hline & Steatoda sp.20/GWB & $\mathrm{p}$ & & & & 0 & 0 & 2 & 0 & 0 \\
\hline & Steatoda sp.6/GWB & 0 & & & & 0 & 0 & 1 & 0 & 0 \\
\hline & Theridiidae sp.22 (genus undetermined)/GWB & 0 & & & & 0 & 20 & 3 & 20 & 1 \\
\hline & Theridiidae sp.23 (genus undetermined)/GWB & 0 & & & & 0 & 0 & 4 & 0 & 1 \\
\hline
\end{tabular}




\begin{tabular}{|c|c|c|c|c|c|c|c|c|c|c|}
\hline \multirow[t]{2}{*}{ Family } & \multirow[t]{2}{*}{ Species/Functional group } & \multirow{2}{*}{$\begin{array}{l}\text { Foord } \\
\text { et al. } \\
2002\end{array}$} & \multirow{2}{*}{$\begin{array}{c}\text { New } \\
\text { records: } \\
\text { post- } \\
2005\end{array}$} & \multirow{2}{*}{ Genera } & \multirow[t]{2}{*}{ Spp. } & \multicolumn{5}{|c|}{ Vegetation type } \\
\hline & & & & & & $M G$ & MW & SF & TF & W \\
\hline & Theridiidae sp.28 (genus undetermined)/GWB & 0 & & & & 0 & 0 & 3 & 2 & 2 \\
\hline & Theridion purcelli O.P.-Cambridge, 1904/GWB & 0 & & & & 0 & 0 & 1 & 0 & 0 \\
\hline & Theridion sp.1/GWB & 0 & & & & 0 & 3 & 87 & 0 & 4 \\
\hline & Theridion sp.3/GWB & 0 & & & & 1 & 11 & 36 & 122 & 17 \\
\hline & Theridion sp.11/GWB & 0 & & & & 0 & 7 & 4 & 9 & 15 \\
\hline & Theridion sp.12/GWB & 0 & & & & 0 & 0 & 6 & 2 & 2 \\
\hline & Theridion sp.13/GWB & 0 & & & & 5 & 48 & 72 & 29 & 27 \\
\hline & Theridion sp.14/GWB & 0 & & & & 0 & 11 & 28 & 10 & 11 \\
\hline & Theridion sp.15/GWB & 0 & & & & 3 & 7 & 1 & 6 & 1 \\
\hline & Theridion sp.16/GWB & 0 & & & & 1 & 8 & 25 & 23 & 31 \\
\hline & Theridion sp.18/GWB & 0 & & & & 0 & 9 & 22 & 14 & 9 \\
\hline & Theridion sp.21/GWB & 0 & & & & 0 & 0 & 1 & 0 & 0 \\
\hline & Theridion sp.30/GWB & 0 & & & & 0 & 1 & 9 & 0 & 2 \\
\hline & Theridion sp.31/GWB & 0 & & & & 0 & 1 & 0 & 0 & 0 \\
\hline & Tidarren cuneolatum (Tullgren, 1910)/GWB & $\mathrm{p}$ & & & & 1 & 8 & 1 & 5 & 4 \\
\hline & Total & & & 13 & 36 & $14(19)$ & $24(171)$ & $23(393)$ & $16(346)$ & $28(170)$ \\
\hline \multirow[t]{42}{*}{ Thomisidae } & Ansiea tuckeri (Lessert, 1919)/FPW & 0 & & & & 1 & 1 & 2 & 1 & 1 \\
\hline & Diaea puncta Karsch, 1884/FPW & $\mathrm{p}$ & & & & 0 & 12 & 18 & 3 & 109 \\
\hline & $\ddagger$ Heriaesynaema sp. (new record SA)/FPW & 0 & & & & 0 & 1 & 0 & 0 & 0 \\
\hline & Heriaeus crassispinus Lawrence, 1942/FPW & 0 & & & & 0 & 1 & 2 & 1 & 2 \\
\hline & Heriaeus fimbriatus Lawrence, 1942/FPW & $\mathrm{p}$ & & & & 1 & 5 & 18 & 6 & 71 \\
\hline & Heriaeus transvaalicus Simon, 1895 & & $\mathrm{p}$ & & & & & & & \\
\hline & Heterogriffus sp.1/FPW & 0 & & & & 0 & 1 & 0 & 0 & 0 \\
\hline & Misumenops rubrodecoratus Millot, 1941/FPW & $p$ & & & & 1 & 5 & 1 & 0 & 14 \\
\hline & Monaeses austrinus Simon, 1910/FPW & $\mathrm{p}$ & & & & 0 & 0 & 0 & 0 & 4 \\
\hline & Oxytate argenteooculata (Simon, 1886)/FPW & $\mathrm{p}$ & & & & 0 & 10 & 9 & 10 & 4 \\
\hline & Oxytate concolor (Caporiacco, 1947)/FPW & $\mathrm{p}$ & & & & 0 & 16 & 1 & 1 & 0 \\
\hline & Oxytate phaenopomatiformis/FPW & 0 & & & & 0 & 1 & 0 & 0 & 0 \\
\hline & Oxytate ribes (Jézéquel, 1964)/FPW & 0 & & & & 1 & 4 & 4 & 1 & 10 \\
\hline & Pactates compactes Lawrence, 1947/FPW & 0 & & & & 0 & 0 & 0 & 0 & 1 \\
\hline & $\begin{array}{l}\text { Pherecydes nicolaasi Dippenaar-Schoeman, } \\
\text { 1980/FPW }\end{array}$ & 0 & & & & 0 & 0 & 5 & 1 & 3 \\
\hline & Runcinia aethiops Simon, 1901/FPW & $\mathrm{p}$ & & & & 1 & 4 & 0 & 0 & 15 \\
\hline & Runcinia flavida Simon, 1881/FPW & $\mathrm{p}$ & & & & 3 & 0 & 0 & 0 & 27 \\
\hline & Simorcus zuluanus Lawrence, 1942/FPW & 0 & & & & 1 & 0 & 1 & 0 & 12 \\
\hline & Smodicinus coroniger Simon, 1895 & & $\mathrm{p}$ & & & & & & & \\
\hline & Synema decens (Karsch, 1878) & & $\mathrm{p}$ & & & & & & & \\
\hline & Synema diana (Audouin, 1826)/FPW & 0 & & & & 0 & 0 & 1 & 0 & 0 \\
\hline & Synema imitator (Pavesi, 1883)/FPW & $\mathrm{p}$ & & & & 1 & 2 & 21 & 19 & 11 \\
\hline & Synema langheldi Dahl, 1907 (first male)/FPW & 0 & & & & 0 & 2 & 16 & 1 & 2 \\
\hline & Synema nigrotibiale Lessert, 1919/FPW & 0 & & & & 1 & 1 & 2 & 0 & 2 \\
\hline & Synema sp.2/FPW & 0 & & & & 0 & 2 & 1 & 0 & 16 \\
\hline & Synema vallotoni Lessert, 1923 (first male)/FPW & W 0 & & & & 0 & 0 & 4 & 0 & 2 \\
\hline & Thomisops bullatus Simon, 1895/FPW & 0 & & & & 0 & 3 & 0 & 0 & 1 \\
\hline & Thomisops pupa Karsch, 1879/FPW & $\mathrm{p}$ & & & & 0 & 0 & 2 & 0 & 0 \\
\hline & Thomisus dalmasi Lessert, 1919/FPW & & $\mathrm{p}$ & & & & & & & \\
\hline & Thomisus daradiodes Simon, 1890/FPW & $\mathrm{p}$ & & & & 1 & 0 & 0 & 0 & 1 \\
\hline & Thomisus granulatus Karsch, 1880/FPW & $\mathrm{p}$ & & & & 1 & 0 & 1 & 1 & 3 \\
\hline & Thomisus kalaharinus Lawrence, 1936/FPW & $\mathrm{p}$ & & & & 1 & 2 & 0 & 1 & 0 \\
\hline & Thomisus scrupeus (Simon, 1886)/FPW & 0 & & & & 0 & 5 & 0 & 0 & 12 \\
\hline & Thomisus spiculosus Pocock, 1901/FPW & 0 & & & & 0 & 0 & 0 & 0 & 16 \\
\hline & Tmarus africanus Lessert, 1919/FPW & 0 & & & & 0 & 6 & 0 & 0 & 1 \\
\hline & Tmarus cameliformis Millot, 1942/FPW & $\mathrm{p}$ & & & & 2 & 7 & 37 & 54 & 54 \\
\hline & Tmarus natalensis Lessert, 1925/FPW & 0 & & & & 0 & 0 & 1 & 0 & 0 \\
\hline & Tmarus planetarius Simon, 1903/FPW & 0 & & & & 0 & 0 & 0 & 1 & 0 \\
\hline & Tmarus riccii Caporiacco, 1941/FPW & 0 & & & & 0 & 0 & 1 & 0 & 0 \\
\hline & tTmarus sp.1/FPW & 0 & & & & 0 & 2 & 23 & 17 & 29 \\
\hline & Xysticus natalensis Lawrence, 1938/FPW & $\mathrm{p}$ & & & & 0 & 0 & 0 & 0 & 2 \\
\hline & Total & & & 17 & 39 & $14(17)$ & $24(105)$ & $23(175)$ & $16(122)$ & $27(439)$ \\
\hline \multirow[t]{2}{*}{ Trochanteriidae } & Platyoides walteri (Karsch, 1886)/FPW & $\mathrm{p}$ & & & & 0 & 0 & 3 & 0 & 1 \\
\hline & Total & & & 1 & 1 & 0 & 0 & $1(3)$ & 0 & 1 (1) \\
\hline
\end{tabular}




\begin{tabular}{|c|c|c|c|c|c|c|c|c|c|c|c|}
\hline \multirow[t]{2}{*}{ Family } & & \multirow[t]{2}{*}{ Species/Functional group } & \multirow{2}{*}{$\begin{array}{l}\text { Foord } \\
\text { et al. } \\
2002\end{array}$} & \multirow{2}{*}{$\begin{array}{l}\text { New } \\
\text { records: } \\
\text { post- } \\
2005\end{array}$} & \multirow{2}{*}{ Genera } & \multirow[t]{2}{*}{ Spp. } & \multicolumn{5}{|c|}{ Vegetation type } \\
\hline & & & & & & & $M G$ & MW & SF & TF & W \\
\hline \multirow[t]{7}{*}{ Uloboridae } & & Hyptiotes akermani Wiehle, 1964/OWB & 0 & & & & 0 & 0 & 14 & 10 & 1 \\
\hline & & $\begin{array}{l}\text { Miagrammopes longicaudatus O.P-.Cambridge, } \\
\text { 1882/OWB }\end{array}$ & p & & & & 0 & 11 & 37 & 10 & 17 \\
\hline & & Miagrammopes sp.2/OWB & 0 & & & & 0 & 0 & 0 & 1 & 0 \\
\hline & & Uloborus lugubris Berland, 1939/OWB & $\mathrm{p}$ & & & & 0 & 5 & 156 & 85 & 3 \\
\hline & & Uloborus plumipes Lucas, 1845/OWB & $\mathrm{p}$ & & & & 1 & 2 & 27 & 11 & 7 \\
\hline & & Uloborus sp.4/OWB & 0 & & & & 0 & 0 & 11 & 5 & 0 \\
\hline & & Total & & & 3 & 8 & $1(1)$ & $3(18)$ & $4(248)$ & $5(122)$ & $3(29)$ \\
\hline \multirow[t]{10}{*}{ Zodariidae } & $>$ & †\#\#Australutica africana/FGW & 0 & & & & 0 & 0 & 0 & 0 & 5 \\
\hline & & Caesetius sp.1/FGW & 0 & & & & 9 & 0 & 5 & 0 & 9 \\
\hline & & Caesetius sp.2/FGW & 0 & & & & 2 & 0 & 0 & 0 & 3 \\
\hline & & †Cyrioctea sp.1/FGW & 0 & & & & 0 & 0 & 1 & 0 & 0 \\
\hline & & Diores auricula Tucker, 1920/FGW & $\mathrm{p}$ & & & & 0 & 0 & 0 & 0 & 0 \\
\hline & & ‡Diores sp.1/FGW & 0 & & & & 0 & 1 & 0 & 0 & 1 \\
\hline & & $\begin{array}{l}\ddagger \text { Psammoduon (undetermined sp.)/FGW } \\
\text { Ranops sp } 1 / \text { FGW }\end{array}$ & $\mathrm{p}$ & & & & 0 & 0 & 0 & 0 & 0 \\
\hline & & Thaumastochilus sp.1/FGW & 0 & $p$ & & & 0 & 0 & 10 & 2 & 4 \\
\hline & & Total & & & 5 & 8 & $2(11)$ & $1(1)$ & $2(16)$ & $1(2)$ & $4(22)$ \\
\hline & & Grand total & & & 156 & 277 & $\begin{array}{c}95 \\
(274)\end{array}$ & $\begin{array}{c}173 \\
(1742)\end{array}$ & $\begin{array}{c}167 \\
(2411)\end{array}$ & $\begin{array}{c}142 \\
(2715)\end{array}$ & $\begin{array}{c}198 \\
(2665)\end{array}$ \\
\hline
\end{tabular}

